ORIGINAL RESEARCH ARTICLE

\title{
How Coopetition Influences the Development of a Dominant Design: Evidence from the Pinball Industry
}

\author{
Fanny Simon' and Albéric Tellier2* \\ 'University of Rouen Normandy, NIMEC UPRES EA 969, Rouen, France; 'Paris-Dauphine University, PSL University, \\ CNRS 7088, DRM (M-LAB), Paris, France
}

\begin{abstract}
Most studies concerning dominant designs focus on 'collective' or 'competitive' strategies that companies deploy to impose their choices on the market. The objective of this research is to assess the extent to which 'coopetitive' strategies may lead to a dominant design. We analyzed the development of a dominant design over an 84-year period through a historical study in the field of pinball machines. Our study focuses on the five main manufacturers of pinball machines and analyzes data from 1930 to 2014 . We demonstrate that companies undergo three phases that involve the progressive development of coopetitive relationships with different impacts on the generation of innovation. Because manufacturers differentiated their offerings, innovated and simultaneously imitated others, increased competition resulted. Simultaneously, external threats and the need to collectively respond to clients and partners prompted the manufacturers to cooperate with one another. Thus, our research provides a better understanding of how specific horizontal coopetitive relationships among manufacturers of the same type of products impact the development of a dominant design at the industry level. This case study suggests that as a theoretical framework, coopetition introduces new insights into the comprehension of relational dynamics during the development of dominant designs. Our observations also confirm or invalidate conclusions drawn in previous works related to coopetition strategies. In particular, this case is interesting as although the appropriability regime was weak, companies still developed coopetitive relationships, contradicting previous studies.
\end{abstract}

Keywords: Coopetition; Dominant Design; Historical Analysis; Innovation; Pinball

Handling Editor: Colette Depeyre. Received: 22 May 20 I7; Accepted: I January 2020; Published: 2 June 2020

S tudies about technology dynamics and technological forecasting have established the concept of dominant design as quasi-paradigmatic (Hekkert \& van den Hoed, 2004; Murmann \& Frenken, 2006). A dominant design corresponds to the specification that defines the product category's architecture. This specification may consist of a single design feature or a complement of design features (Anderson \& Tushman, 1990; Christensen, Suárez, \& Utterback, 1998; Srinivasan, Lilien, \& Rangaswamt, 2006).

The selection of a dominant design corresponds to a key moment in the process of technological development (Murmann \& Frenken, 2006; Tushman \& Murmann, 1998). This process is characterized by a first period of disruption associated with the development of several technological options and a gradual convergence on a limited number of alternatives, which leads to the selection of a dominant design. After this selection, a phase of incremental innovations begins, which reinforces the dominant design (Abernathy \& Utterback, 1978; Anderson \& Tushman, 1990; Murmann \& Freken, 2006).

Since the pioneering work of Abernathy and Utterback (1978), researchers have focused on defining the concept of dominant design, its underlying causal mechanisms, its level of analysis, its effects on environmental conditions, and the evolution of industrial organizations (for a review, see Murmann \& Frenken, 2006). Several authors have demonstrated that the 'strategic maneuvers' (Cusumano, Mylonadis, \& Rosenbloom, 1992) of companies can explain the outcomes of competitions among different dominant designs (Rosenbloom \& Cusumano, 1987; Suárez \& Utterback, 1995).

This literature concerning dominant designs focuses on deploying either 'competitive' or 'collective' strategies. However, focusing only on these two relational logics to understand firm

*Corresponding author: Albéric Tellier, Email: alberic.tellier@dauphine.psl.eu 
actions downplays more complex forms of relationships. Technological arrangements among firms do not always lead to a decrease in competitive rivalries or a dearth of innovations over the long run (Shibata, 1993). In fact, companies may simultaneously target a collective strategy to make the technological know-how more transferable and tradable and protect their technology from imitators to foster its appropriability regime (Hurmelinna-Laukkanen \& Puumalainen, 2007; Shapiro \& Varian, 1998; Teece, 1986). They would then simultaneously use patents, secrets, knowledge tacitness and control of human resources turnover to avoid knowledge leakage (HurmelinnaLaukkanen \& Puumalainen, 2007) and license their technology or give access to their competitors to certain components to facilitate adoption (Ehrhardt, 2004).

Hence, more attention should be paid to 'coopetitive strategies,' which involve both cooperation and competition. We define coopetition as relationships that simultaneously involve collaboration and competition. In coopetition, companies simultaneously balance collective and individual interests (Gnyawali \& Park, 20I I). Thus, they collaborate to create common value and compete to reap benefits by appropriating a bigger share of the created value (Brandenburger \& Nalebuff, 1995).

To our knowledge, very few researchers have deeply analyzed this type of relationship during the formation of a dominant design. Although there is a significant amount of research to explain why a dominant design emerges in an industry, the literature is less clear regarding how dominant designs emerge and how firms behave to impose their product as a dominant design (Funk, 2003).

Thus, our research question is as follows: how do specific horizontal coopetitive relationships among manufacturers of the same type of products impact the development of dominant designs at the industry level? To achieve this objective, we undertake a historical study of the development of a dominant design within the pinball machine industry. Our study focuses on the five main manufacturers of pinball machines - all located in Chicago - and analyzes data for a long time period: from 1930 to 2014 .

The first part of this article presents the study's theoretical framework and research objectives, and the second part describes its methods. The historical analysis is based on four types of data: books on pinball history, articles from the economics and specialty literatures, patents in full-text from the USPTO database, and discourses from 32 industry representatives that were collected from different sources. The results are described in the third part of the article and discussed in the fourth part.

This research shows how coopetitive relationships lead to a dominant design and how those relationships form and evolve. In the pinball machine industry, the dominant design was not imposed by a single organization 'riding alone,' nor did the dominant design result from a prior agreement among industry participants favoring a collective strategy. It came from both strategic maneuvers deployed by manufacturers and triggers from third parties and the external context. As manufacturers differentiated their offerings, innovated and simultaneously imitated others, increased competition resulted. Simultaneously, external threats and the need to collectively respond to clients and partners prompted the manufacturers to cooperate with one another.

Furthermore, our case study highlights specific characteristics and gives evidence contradictory to the established literature. Hence, the ability of manufacturers to regularly and quickly integrate new technologies to strengthen the dominant design demonstrates a strong absorptive capacity. Moreover, this study highlighted that the pinball machine industry was characterized by a weak appropriability regime. In particular, mechanisms of institutional protection (more particularly patents) provided a fragile protection, as indicated by short imitation delays. These results highlight conditions in which coopetition can emerge in spite of a weak appropriability regime, which brings new insights to the work of Ritala and Hurmelinna-Laukkanen (2013).

\section{Theoretical background}

\section{The development of a dominant design in the technology life cycle}

The integration of new technologies in products, processes, or services is often characterized by conflicts among both competitors and coalitions or associations (Tushman \& Murmann, 1998; Von Burg \& Kenney, 2003). However, existing firms gradually converge around common choices (Geroski, 1995), and a dominant design is eventually enforced (Abernathy \& Utterback, 1978). Developing a dominant design and establishing new designs involve a process comprising four phases (Anderson \& Tushman, 1990; Funk, 2003; Murmann \& Frenken, 2006): emergence, fermentation, selection, and incremental change.

The first phase corresponds to the emergence of a technological disruption, which can renew the core competencies and assets of an industry. This disruption affects either the product or the processes associated with the product (design, manufacturing, distribution...) (Anderson \& Tushman, 1990). Regarding the product, disruption results in the emergence of a new category of product, the substitution of one product by an alternative product, or a significant improvement in the performance of existing products (Tushman \& Anderson, 1986).

The second phase of the process is the 'era of ferment.' During this phase, competition occurs not only between the new technology and older products and/or services but also among different technological options. New actors, including 
both existing companies and new entrants, are motivated by the opportunities offered by new technologies and try to exploit them. As companies search for the 'best solutions' to launch in a market, they often propose several technological innovations without improving industrial processes. Thus, several versions of the product are released to the market (Klepper, 1996), each based on alternative technological options and/or specific configurations.

The third phase corresponds to the selection of a dominant design. This phase starts with the development of a version that is more attractive for a significant number of users, compared to earlier products. This new design does not usually include radical innovations but rather is a creative synthesis of innovations that were introduced independently (Murmann \& Frenken, 2006). Then, several actors converge gradually on one option to favor the adoption of their products (Schubert, Sydow, \& Windeler, 2013; Sydow, Windeler, Schubert, \& Möllering, 2012) and contribute to the achievement of a dominant design. Eventually, the dominant design is considered as the design "that wins the allegiance of the marketplace, the one that competitors and innovators must adhere to if they hope to command significant market following" (Utterback, 1994, p. 24). Dominant designs could encompass the whole product and/or individual components of the product (Murmann \& Frenken, 2006). The dominant design could rely on a single technology or on a combination of technologies (Christensen et al., 1998).

As the establishment of a dominant design reduces the number of alternatives, it enhances the economy of scale, reduces uncertainty in the market, and enforces standardization (Abernathy \& Utterback, 1978). The existing literature is not very clear regarding the differences between standards and dominant designs. Some prior research has used the terms interchangeably, and terms such as 'standards wars' have been used to denote the battle between designs (Shapiro \& Varian, 1998; Srinivasan et al., 2006). The term 'standard' must be used to denote the technical specifications for reference, compatibility, and connectivity that are required for the proper functioning of products that must be connected with others (such as DVDs, smartphones, and PCs). Standards in a product category serve to enhance functional acceptance, which does not relate to market acceptance. Conversely, market acceptance is an integral aspect of dominant design (Srinivasan et al., 2006). In this paper, in accordance with the work of Funk (2003), we define a 'standard' as an interface standard and a 'dominant design' as a product (or subproduct) architecture. For example, smartphones have different standards (the 'air-interface' standard, 'operating system' standard, 'software-hardware' interface...), but a dominant design has emerged since the launch of the iPhone.

The fourth phase is the 'era of incremental change.' This phase is characterized by gradual improvements in currently exploited technologies, which reinforce the dominant design (Tushman \& Anderson, 1986). Companies then favor exploitation, which involves the efficient use of existing knowledge (March, 1991). Thus, the assets and competencies of existing companies are closely built into the chosen design, which makes organizations more vulnerable to major technological disruption. Unsurprisingly, a technological disruption results in a new cycle that challenges the dominant design.

Throughout the technological cycle, innovations are launched, and different types of innovations predominate during the three phases of the dominant design formation. Furthermore, those innovations can relate to a core concept or a particular component, as a product, like any other complex system, does not correspond only to an assembly of interacting elementary components but rather consists of a nested hierarchy of different subsystems (Simon, 1962; Murmann \& Frenken, 2006). Thus, according to Henderson and Clark (1990), four types of innovation can be distinguished during the technological cycle (Table I).

A radical innovation establishes a new product category using new components and introduces a paradigm shift. It is often associated with the introduction of a new technology. This type of innovation mainly appears in the first phase of the technological cycle. Architectural innovations concern changes in the association among the concepts and product components.

It is mostly associated with the 'fermentation' phase of the technological cycle as actors are searching for the best design to satisfy the market. Those changes in architecture lead to numerous product innovations, as shown by Abernathy and Utterback (1978). The establishment of a dominant design emerges as the majority of actors accept the product architecture. After the selection of the dominant design, actors favor incremental innovations or modular innovations that renew the concept (notably by adding a component or a feature) without disrupting all components.

\section{Strategic maneuvers: A causal mechanism in the development of dominant designs}

Scholars of dominant designs have appealed to a variety of underlying causal mechanisms to explain why a particular

Table I. Henderson and Clark's (1990) innovation framework

\begin{tabular}{lcc}
\hline \multirow{2}{*}{$\begin{array}{l}\text { conkages between core } \\
\text { components }\end{array}$} & \multicolumn{2}{c}{ Core concepts } \\
\cline { 2 - 3 } Unchanged & Reinforced & Overturned \\
Changed & Architectural innovation & Radical innovation \\
\hline
\end{tabular}

Source: Henderson and Clark (1990, p. 12). 
design emerges as the dominant design (Murmann \& Frenken, 2006). They can be classified into four categories:

I. A design becomes dominant because it represents the best technological compromise between the different functional characteristics of the technology (Christensen et al., 1998; Suárez \& Utterback, 1995).

2. The selection of a dominant design is caused by the existence of network effects and economies of scale that create dynamic, increasing returns (Arthur, 1989; Cecere, Corrocher, \& Battaglia, 20 I5; Katz \& Shapiro, 1985).

3. A dominant design emerges through a combination of sociological, political and organizational dynamics (Tushman \& Rosenkopf, 1992). In particular, actor network theory (Akrich et al (2002a, b); Bijker, Hughes, \& Pinch, 1989) focuses on the influence of conflicting interests and trade-offs between different actors on innovation characteristics.

4. The strategic maneuvers followed by firms to address their competitors influence the development of a dominant design (Cusumano et al., 1992; Rosenbloom \& Cusumano, 1987; Suárez \& Utterback, 1995).

The selection of a dominant design implies that actors lead toward similar options. Imitation and collaboration, for example, are cornerstones in the process of dominant design development. However, the stabilization of a dominant design depends on relationships that firms have (or do not have) with their competitors. Those relationships can involve three different logics: confrontation, cooperation, and avoidance (Kœnig, 2004). These three logics can be used to define three 'strategic maneuvers' (Cusumano et al., 1992) that can lead to a dominant design (Figure I).

A 'competitive strategy' (Figure I) means that the innovative firm attempts to impose its own design and favors

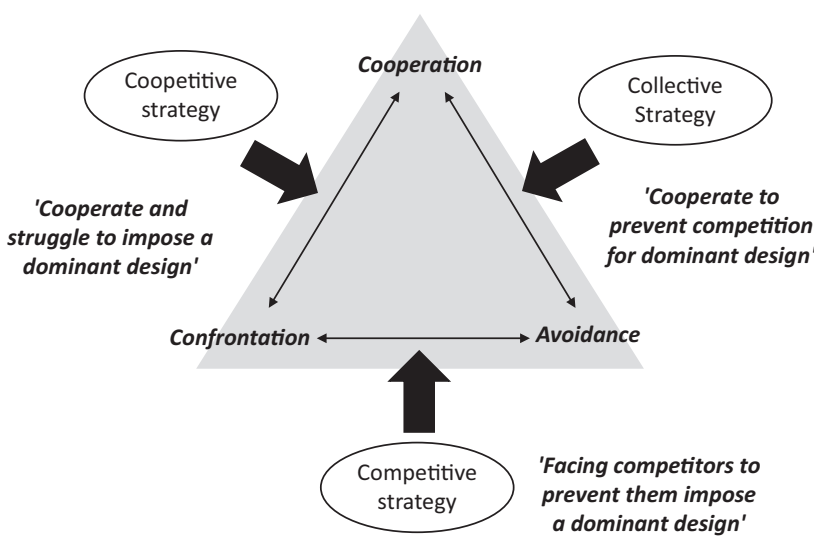

Figure I. Imposing a dominant design: Three types of strategic maneuvers competition with alternative technologies and products. As the innovative firm attempts to obtain substantial returns, that firm (which 'rides alone') may enhance its technology leadership to obtain (at least for some time) a technology monopoly and to discourage the launch of competitive products. The firm that originated the winning design flourishes, whereas other firms that invested in alternative designs incur economic losses (Murmann \& Frenken, 2006). Fernández and Valle (2019) noted that this strategy occurs during the emergence of de facto dominant designs, which are derived from market selection. In those instances, the pioneering firm (which may have launched a disruptive technology) needs to invest considerable resources to conquer a large customer base, such as Intel with its microprocessor.Then, the firm can usually convince customers and suppliers that it is winning the game through advertising and statements. The success of this type of strategy depends on the appropriability regime (Teece, 1986). The appropriability regime of a firm is defined as the extent to which innovations can be protected from imitators. "It consists of appropriability mechanisms - the means of protecting both the innovation itself and the increased rents due to research and development" (Hurmelinna-Laukkanen \& Puumalainen, 2007, p. 96). If appropriability is low, competitors will be able to easily imitate the design defined by the pioneering firm. However, a high appropriability regime can lead to the development of independent market segments (local monopolies) and hamper the formation of a unique dominant design (Cecere et al., 2015).

As a 'collective strategy' is fostered (Astley \& Fombrun, 1983), cooperation is favored to avoid confrontation between different designs. In certain industries, actors know that they should converge on one technological option to favor the adoption of a new technology (Schubert et al., 2013; Sydow et al., 20I2). Consequently, companies shape a network of relationships with other firms to foster the development of a dominant design (Ehrhardt, 2004; Garud, Jain, \& Kumaraswamy, 2002). This goal of collectively defining technologies and dominant design requires formal agreements between firms and leads to coalitions, research and development (R\&D) collaborations, licensing, and the development of broad networks of companies (Cusumano et al., 1992; Dussauge \& Garrette, 1999; Liebowitz \& Margolis, 1995; Murmann \& Frenken, 2006; Soh, 2010). Actors can also set up an intermediation structure to define standards, coordinate and control the actions of members, and develop agreements with other actors (e.g., the 'DVD Forum' created by 10 of the biggest players in the consumer electronics industry to develop a new design in the video market as a replacement for the Video Home System) (King et al., 1994). Existing studies about dominant design demonstrated that its success depends on the abilities of innovative firms to garner a community to support the new technology (Ehrhardt, 2004; Garud \& Karnøe, 2003; Soh, 201 0; Von 
Burg \& Kenney, 2003). Companies derive 'relationship benefits' (Dyer \& Singh, 1998) through the adoption of a collective strategy, such as pooling of critical resources, identification of opportunities, generation of awareness about the technology, reduction of the perceived uncertainty, and diminution of competing alternatives (Ehrhardt, 2004).

As a 'coopetitive strategy' is followed (Figure I), firms cooperate and compete simultaneously to impose a dominant design. The main challenge is then to find the right amount of cooperation to enhance value creation as well as the appropriability regime to obtain a return on the innovation investment (Hurmelinna-Laukkanen \& Puumalainen, 2007; Ritala \& Tidström, 2014). A firm engaged in coopetition tries to learn from its competitor but needs to prevent imitation to retain its cutting-edge advantage. Thus, the firm's ability to acquire knowledge from external sources (absorptive capacity) (Cohen \& Levinthal, 1990) and to protect its innovations from imitation (appropriability regime) are key elements in fostering the positive outcomes of collaborating with competitors (Ritala \& Hurmelinna-Laukhanen, 2013). The deployment of coopetitive relationships has also been demonstrated to be a possible strategy for standardization (Mione, 2009) and the emergence of a dominant design (Yami \& Nemeh, 20l4). Certain relationships have been highlighted to achieve that goal: companies should avoid collaboration with close rivals (Ehrhardt, 2004) or with only horizontal competitors (Lee, 2007). However, to our knowledge, very few researchers have deeply analyzed the effects of these coopetitive relationships on the formation of a dominant design. Actually, most works focus on either competitive strategies to gain an advantage on the market, suggesting that the company aims to exploit the design exclusively, or cooperative strategies to compete on the market and gain competitor support by opening the design (Fernández \& Valle, 2019), but the impact of coopetitive relationships is unknown.

\section{Coopetitive relationships and innovative outcomes}

Although coopetition has become a prominent research stream in the management literature, the concept of coopetition is still defined in different ways (Peng,Yen, \& Bourne, 20 I 8), and the field of research is still fragmented (Bengtsson, Kock, \& Lundgren-Henriksson, 2019). In many recent studies, coopetition is often widely defined as cooperation with competitors (Jakobsen \& Steinmo, 2016; Ritala \& Tidström, 2014; Yami \& Nemeh, 20l4). However, we prefer to adopt a narrower definition, which allows a better understanding of the concept and its implication (Fernandez, Le Roy, \& Gnyawali, 2014). Consequently, we follow Gnyawali and Park's (20 I I) perspective and consider that two conditions are necessary for a situation to be characterized as coopetitive:
I. Competition and cooperation occur at the same time (simultaneity criteria)

2. Companies maintain horizontal competitive relationships (rivalry criteria)

According to Figure I, simultaneous confrontation and collaboration clearly sets coopetition apart from other types of interorganizational relationships (Ritala \& Tidström, 20l4). Many empirical studies have been performed to demonstrate the relevance of coopetition in business life and research (Bengtsson et al., 2019; Bouncken, Gast, Kraus, \& Bogers, 2015; Gnyawali \& Song, 2016). Numerous researchers have attempted to analyze the drivers, antecedents, and determinants explaining why firms adopt coopetition strategies. According to Bengtsson and Raza-Ullah (2016) and Mariani (2019), it is possible to distinguish the following three partially overlapping categories of coopetition drivers: relation-specific, external and internal drivers. Some relation-specific drivers have been identified. Czakon and Czernek-Marszalek (2019) explained how different trust-building mechanisms encourage competitors to enter coopetitive relationships. Klymas (2019) identified organizational cultural features and cultural models that could drive coopetitive relationships in different industries.

The external drivers include environmental conditions, such as technological demand, industrial characteristics, and influential stakeholders (Mariani, 2019). Ties with third party and vertical partners of coopetitors play a substantial role both in the formation of coopetitive relationships and in their evolution (Bengtsson \& Kock, 2000; Chiambaretto \& Rigaud, 2013; Fernandez et al., 20l4). Hence, customers may require competitors to develop collaborative relationships to launch bundle offerings (Chiambaretto \& Dumez, 2012; Choi, Garcia, \& Friedrich, 2009). Other external drivers, including the influence of regulatory bodies and policy makers (Bengtsson \& RazaUllah, 2016; Castaldo, Möellering, Grosso, \& Zerbini, 20l0; Depeyre \& Dumez, 2010; Dorn, Schweiger, \& Albers, 2016; Mariani, 2019), have been highlighted. Those third parties also influence the development of coopetitive relationships and the rate of innovation launched on the market. They are described both as coordinating the coopetitive relationships (Bengtsson \& Kock, 2000) and creating tensions among coopetitors to benefit from the conflict (Fernandez et al., 20।4).

The internal drivers include firms' goals, resources, and capabilities. A major internal driver of coopetition strategies is innovation (Bengtsson \& Kock, 20l4; Fernandez, Le Roy, \& Chiambaretto, 2018; Gnyawali \& Park, 2009, 201 I; Ritala \& Hurmelinna-Laukkanen, 2009). High market uncertainty, low competition intensity, and high network externalities increase the positive effect of coopetition on innovation (Ritala, 2012) as well as the appropriability regime and absorptive capacity (Ritala \& Hurmelinna-Laukkanen, 2012). 
Scholars have mainly focused on innovation as an outcome of a coopetition strategy. They have found mixed results, which indicate that there is a gap in our knowledge and a lack of consensus (Jakobsen \& Steinmo, 20 I 6; Ritala, Kraus, \& Bouncken, 2016). Furthermore, most papers on these topics study the effect of different relational strategies on the firm's outcome (such as the firm performance) (Hamouti, Robert, \& Le Roy, 20।4; Ritala \& Hurmelinna-Laukkanen, 2009; Tomlinson, 20 I0) and do not analyze the effect of individual coopetitive strategies on an industry. Thus, coopetition and its impact on industry changes have been underresearched, particularly over long time spans (Czakon \& Dana, 20।3).

Our objective was to study the evolution of coopetitive relationships over a long period of time, which allows us to gain a better understanding of the outcomes of those relationships in terms of innovation generation and industry evolution through the development of a dominant design. We consider horizontal coopetitive relationships among designers of the product as part of a broader network of relationships (which are not characterized as coopetitive). Thus, as proposed by Ritala and Tidström (2014), we address the problem concerning the impact of coopetitive strategies not only at the dyadic level but also at a broader level of analysis including all actors involved in the development of the dominant design. Furthermore, existing works concerning coopetition have overlooked the variations in the intensities of coopetitive relationships and the balance between coopetition and competition (Gnyawali \& Ryan Charleton, 2018). Gnyawali and Ryan Charleton (2018) defined such a balance as the evenness between cooperation and competition, and emphasized the stability and positive consequences of such a balance. However, these authors mentioned that it is difficult to achieve an ideal balance and that the content of the relationships oscillate around this model. Thus, in our article, we adopt such a perspective.

To answer our research question regarding the impact of specific horizontal coopetitive strategies on the development of a dominant design at the industry level, we perform a historical study of the development of a dominant design in the field of pinball machines.

\section{Methods}

\section{Research design and case selection}

\section{Research design}

This research is based on a longitudinal case study. Due to limited research on coopetitive relationships in dominant design formation, a qualitative approach was adapted for this study (Stake, 1994). A historical case study design was used to examine how coopetition leads to a dominant design for two main reasons. First, the use of historical case studies is recommended to address 'how' questions (Yin, 2009). Second, a historical analysis is particularly suitable for research regarding technological developments; as these developments are characterized by evolution and disruptions, it is essential to refer to their changes over a long period of time.

\section{Case selection}

As part of a research program about the skill games sector,' we performed a historical analysis of the development and decline of pinball from 1930 to 2014 (Tellier, 2015, 2017). The said project started with an opportunity to collect abundant data on the history of pinball industry. The first analyses demonstrated that the leading manufacturers of those machines managed to impose a dominant design and maintain a favorable competitive position until the 1990s. We realized that the dominant design was enforced without a formal agreement among manufacturers and implementation of intermediation structures. Over the period that was studied, we identified competitive as well as collaborative relationships concomitant to the development of the dominant design. Consequently, by studying the development of the leaders of the pinball industry in the United States, we identified an unexpected observation that led us to change our initial research program by studying how coopetitive relationships may lead to a dominant design. Thus, this single-case study can be considered a 'revelatory case' (Yin, 2009).This situation exists when a researcher has an opportunity to observe and analyze a phenomenon.

\section{Case study presentation}

A pinball machine is an arcade game in which a player scores points by manipulating one or more steel balls on a playfield inside a glass-covered cabinet. This particular arcade game became popular in the United States toward the end of the 1920s in the context of Prohibition and the economic crisis, particularly as 'Penny Arcades' were established (Huhtamo, 2005). Our analysis focused on the five primary pinball manufacturers: three worldwide leaders (Bally, Gottlieb, and Williams) and two outsiders (Chicago Coin and Genco, which merged at the end of the 1950s).

Some European and Japanese manufacturers tried to enter this market. These actors remained marginal. For example, in Japan, a total of 25 models of pinballs were introduced by Sega from 197| to 1979 but were mainly for the local market. Until the mid-1990s and in spite of the emergence of video games at the beginning of the 1980s, pinball manufacturers continued to experience high turnover. However, that time period ultimately led to the decline of the pinball machine industry (Tellier, 2017). In 1977, Chicago Coin was sold and had

\footnotetext{
1. The skill game sector includes firms specializing in the production, distribution, and operation of gaming devices that offer no winnings to players. It is basically foosball, pinball, billiards, arcade games and darts.
} 
ceased operations by 1985. Bally was purchased by Williams in 1988, and Gottlieb closed in 1996. Williams attempted to develop new models that combined pinball and video games but was forced out of business in 1999. Since 2000, there has been only one manufacturer of pinball machines worldwide, Stern, which releases only three or four new models every year.

Role repartition in the pinball industry was as follows (Figure 2). Manufacturers designed and produced a new model, then purchased components from different suppliers and obtained licenses from Hollywood studios or entertainers to differentiate their products. In addition, manufacturers relied on independent designers. Pinball machines were then distributed to operators who purchased them. Thus, these operators were the direct customers of the manufacturers, and they marketed to arcade rooms that rented the machines. Profits earned on each machine were shared between the owner of the arcade room and the operator (approximately 50\% each). The operator maintained and repaired the machines, which typically entailed maintaining a supply of spare parts for these repairs.

\section{Data collection and data analysis}

\section{Data collection}

In this research, we use secondary data (Silverman, 2000), that is, data that have already been gathered by someone else. More precisely, we use materials diverted from the purposes for which they were originally collected and processed to become part of a new research project. Consequently, this research can be characterized as an 'assorted analysis'
(Chabaud \& Germain, 2006; Heaton, 2004). With this kind of research, it is important to carefully consider the quality of the collected data (Stewart, 1984).

Our historical analysis is based on four types of data. First, we used books and encyclopedias about the history of pinball machines (Colmer, 1976; Rossignoli, 201 I; Ruben, 2018; Shalhoub, 2002, 2004, 2005) that provided detailed data regarding different versions, quantities manufactured, technologies, and innovations used in the industry. Then, articles were collected from the economics and various specialized presses. We also conducted a study on the United States Patent and Trademark Office (USPTO) patent full-text database. This database lists the complete texts of patents since 1976. For the three leading pinball manufacturers of this period (Bally, Gottlieb, and Williams), we collected 123 patents. Finally, we registered and analyzed interviews by individuals who had worked in the pinball machine industry (manufacturers, design agencies, arcade staff, etc.) and/or who had studied its development. These interviews had been filmed for video programs regarding the industry and its history and constitute a total of 9 h of recording (Batson \& Bellgraph, 2008; Helms, Cook, \& Fisher, 1997; Maletic, 2010; Sullivan, Jacobsen, \& Rickard, 2010). In addition, written interviews were collected and analyzed. The community website, 'The Pinball Blog,' provides free access to interviews with pinball professionals. Included in our analysis were interviews published in extenso (approximately 550 pages) in the first five volumes of the Pinball Magazine and a special edition (Joosten, 2012-2018). Finally, we obtained access to interviews with 32 actors in the pinball industry (Table 2). These interviews were recorded between 1997 and 2018.

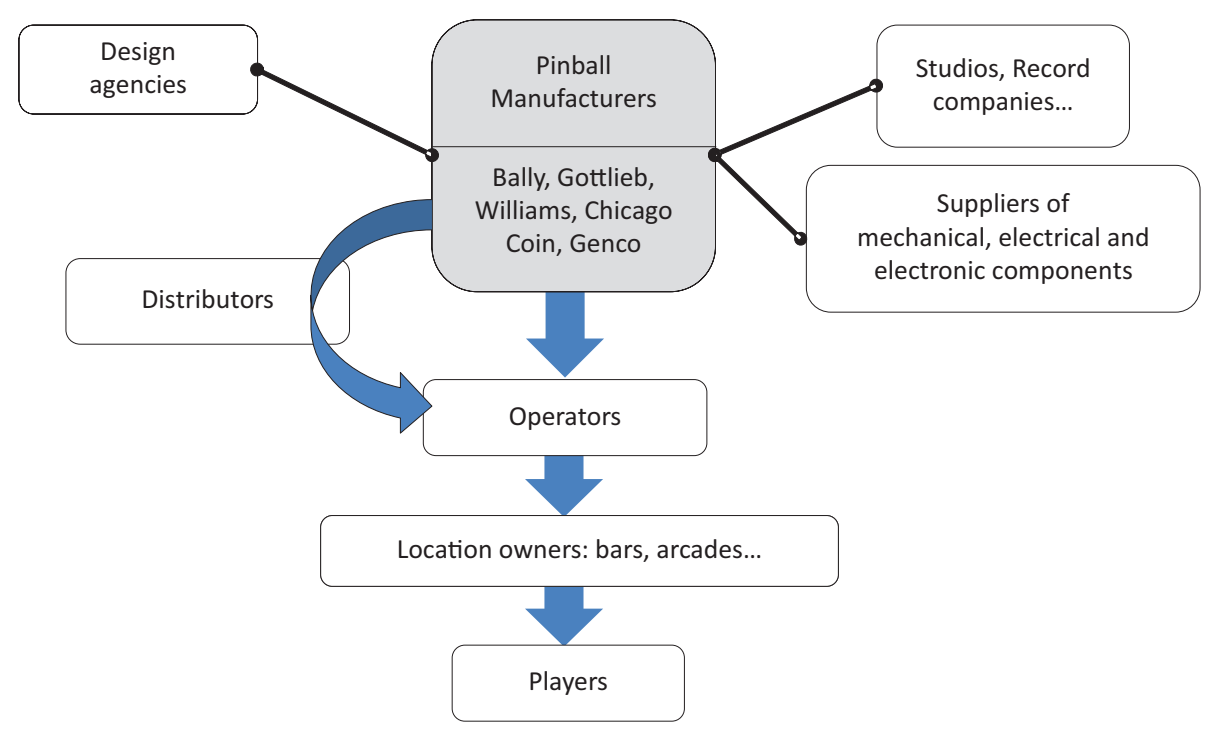

Figure 2. Key actors in the pinball industry 


\section{Data analysis}

We performed an empirical analysis in three stages, which are presented below.

Stage 1: Historical analysis. First, we conducted a historical analysis of the development and decline of the pinball industry. This allows us to highlight the technologies that were used, the various products that were launched, and to identify the main actors and their relationships. Books were the primary sources of information used to construct a detailed chronology. That chronology was progressively developed using other sources that were collected. We add complementary data until we achieve saturation (Glaser \& Strauss, 1967).

Stage 2: Characterization of the development of the dominant design. To characterize the development of the dominant design, we identify the main product innovations and successive models of pinball machines from 1930 to 2014.

Table 2. Sources of interviews

\begin{tabular}{|c|c|c|c|c|c|c|c|}
\hline \multirow[t]{2}{*}{ ID number } & \multirow[t]{2}{*}{ Title } & \multicolumn{6}{|c|}{ Sources } \\
\hline & & $\begin{array}{l}\text { The } \\
\text { Pinball } \\
\text { Blog }\end{array}$ & $\begin{array}{c}\text { Pinball } \\
\text { Magazine, } n^{\circ} \mid-5 \text { \& } \\
\text { Special Issue, } \\
2012-2018\end{array}$ & $\begin{array}{c}\text { Pinball } \\
\text { Passion, } \\
\text { Documentary, } 2008\end{array}$ & $\begin{array}{c}\text { The History } \\
\text { of Pinball, } \\
\text { Documentary } \\
1997\end{array}$ & $\begin{array}{c}\text { Special } \\
\text { When Lit, } \\
\text { Documentary, } 2010\end{array}$ & $\begin{array}{c}\text { Tilt, The Battle to } \\
\text { Save Pinball, } \\
\text { Documentary } 2010\end{array}$ \\
\hline I & $\mathrm{GD}, \mathrm{MK}, \mathrm{HL}$ & $x$ & $x$ & $x$ & $x$ & $x$ & \\
\hline 2 & GD & $x$ & & & $x$ & $x$ & $x$ \\
\hline 3 & GD & $x$ & & & & & $x$ \\
\hline 4 & GD & $x$ & & $x$ & & $x$ & \\
\hline 5 & GD & $x$ & & & & & \\
\hline 6 & 1 & $x$ & & & & & \\
\hline 7 & $E$ & $\mathbf{x}$ & & & & & \\
\hline 8 & GD & $x$ & & & & & \\
\hline 9 & GD & & $x$ & $x$ & & & \\
\hline 10 & I & & $x$ & & & & \\
\hline II & GM & & & $x$ & & & \\
\hline 12 & GAM, O & & & $x$ & & $x$ & \\
\hline 13 & GD & & $\mathbf{x}$ & $x$ & & & \\
\hline 14 & GAM & & & $x$ & & & \\
\hline 15 & SD & & & $x$ & $x$ & & \\
\hline 16 & GD & & & $x$ & & $x$ & $x$ \\
\hline 17 & $\mathrm{E}$ & & & $x$ & & & \\
\hline 18 & GM & & & $x$ & & $x$ & \\
\hline 19 & $\mathrm{H}$ & & & & $\mathbf{x}$ & & \\
\hline 20 & GAM, O & & & & & $x$ & \\
\hline 21 & $\mathrm{HL}$ & & $x$ & & & $x$ & \\
\hline 22 & GD, GM & & & & & & $x$ \\
\hline 23 & GD & & $x$ & & & & $x$ \\
\hline 24 & SD & & & & & & $x$ \\
\hline 25 & SD & & & & & & $x$ \\
\hline 26 & PPS & & & & & $x$ & \\
\hline 27 & GD & & $x$ & & & & \\
\hline 28 & GD & & $\mathbf{x}$ & & & & \\
\hline 29 & I & & $x$ & & & & \\
\hline 30 & E & & $x$ & & & & \\
\hline 31 & SD, GD & & $x$ & & & & \\
\hline 32 & $\mathrm{GD}, \mathrm{SD}, \mathrm{HD}$ & & $x$ & & & & \\
\hline
\end{tabular}

GD: Game Designer, MK: Marketer, HL: Head of Licensing, E: Engineer, I: Illustrator, H: Historian, HD: Hardware Designer, SD: Software Designer, O: Operator, GAM: Game Arcade Manager, GM: General Manager, and PPS: Pinball Parts Seller. 
We used data triangulation by including data from four main sources:

I. The listing, proposed by Rossignoli (201 I), includes 3,000 models produced between 1933 and 1998. That listing details the characteristics of the different models.

2. The three books by Shalhoub $(2002,2004,2005)$ present all models produced year after year between 1932 and 2005 and provide information on the main innovations. Pictures of pinball machines and, more particularly, the screening of playfields allow us to identify the adoption of specific features.

3. The Internet Pinball Database (IPDB) provides a list of 5,990 pinball machines, poll tables, and gambling games produced between 1926 and 2014, as well as the technical features of several models.

4. The Internet Pinball Serial Number Database (IPSND) collects the serial numbers of pinball machines and publishes a database of pinball machines produced between 1931 and 2016.

The combination of these data allowed us to detect the arrival of the main product innovations and track the development of the dominant design (Figure 3). We discovered events on the emergence of innovations or the dropout of specific characteristics. A total of 59 main product innovations were identified (Table 5). Because dominant designs could encompass the whole product and/or an individual module of the product (Murmann \& Frenken, 2006), these innovations were classified into three categories: architectural, modular, incremental (Henderson \& Clark, 1990; Smith \& Tushman, 2005). In accordance with Henderson and Clark's (1990) work, we do not label changes to pinball design as radical innovations. A radical innovation establishes a new product category using new components and introduces a paradigm shift. Consequently, we only consider the launch of the first pinball machine and later the introduction of video games to replace pinball machines to be radical innovations. A radical innovation is often associated with the introduction of a new technology. However, in the pinball industry, new technologies, which were integrated after 1970 by manufacturers, reinforced the dominant design.

We also assessed the time lag between the emergence of a product innovation and its integration in the dominant design. Anderson and Tushman (1990) defined a dominant design "as a single configuration or a narrow range of configurations that accounted for over 50 percent of new products sales or new

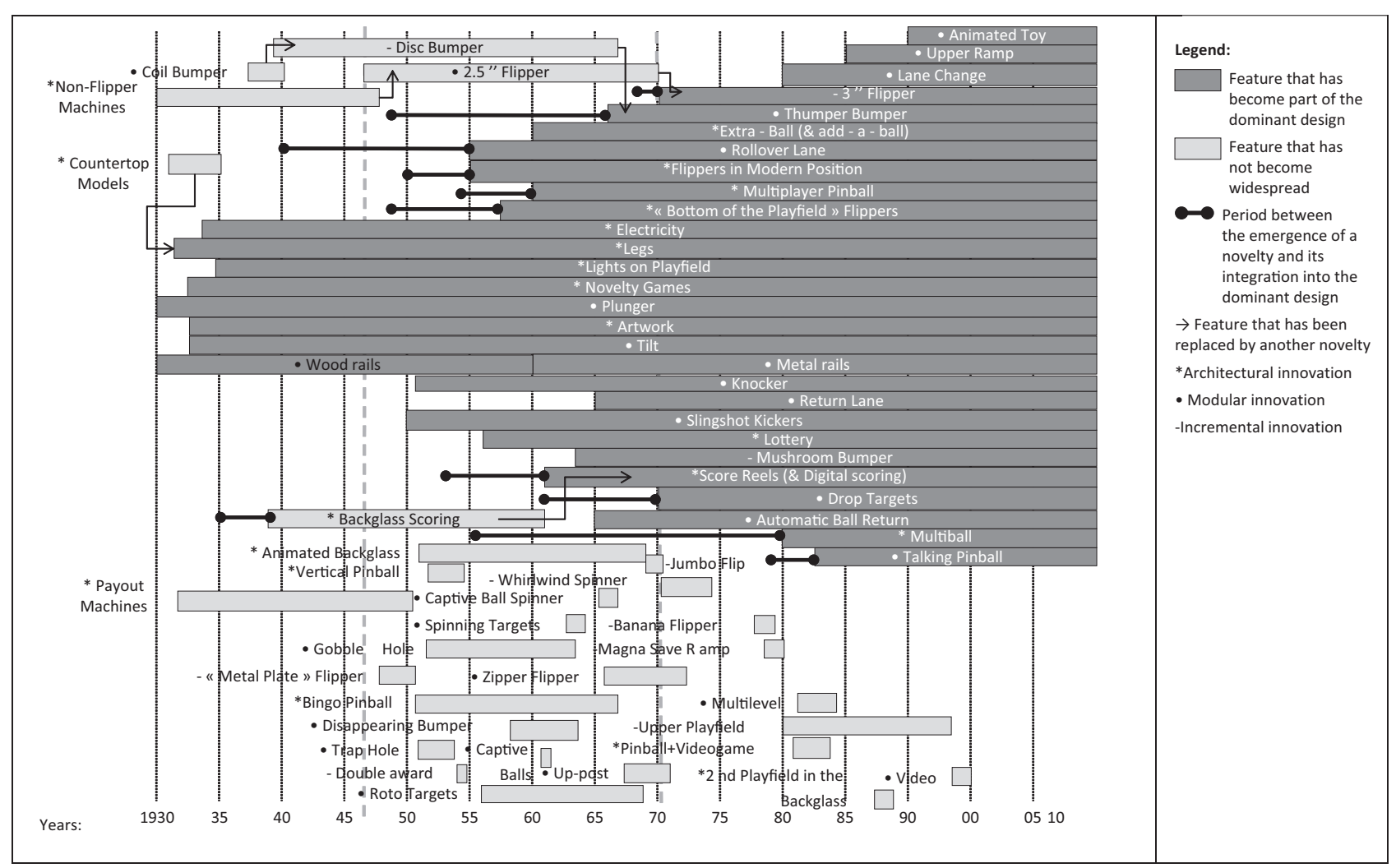

Figure 3. Chronological analysis of the development of the dominant design (1930-2014) 
process installations and maintained a 50-percent market share for at least four years." Because sales figures of the different models are not available, we considered that a specific feature incorporates (or not) the dominant design if we could track it (or not) on 50\% of the models designed or when the three main manufacturers integrated the feature (Bally, Gottlieb, and Williams). In Figure 3, we represent those features that have become part of the dominant design and those that have not become widespread. We also highlight changes in the dominant design by indicating the features that were replaced by others as well as the length of time before a new characteristic became integrated into the dominant design.

Stage 3:Thematic analysis of interviews. As we collected data from numerous interviews, we needed to simplify the data. First, we selected relevant paragraphs addressing our research topic (Huberman \& Miles, 2002). This step was crucial, as the interviews had not been performed by the authors of this paper and addressed various subjects.

Then, these excerpts from interviews were coded. Our approach was inspired by the work of Fernandez et al. (2014), who combined literature-based conceptual arguments and insights from in-depth study of one exemplar case of coopetition. The coding was based on the literature review. The first objective was to identify coopetitive relationships between pinball manufacturers. The second objective was to identify the dimensions of coopetition strategies related to the development of a dominant design. Consequently, we obtained the first list of codes from a literature review related to coopetition. Particularly, we differentiate between cooperative and competitive behaviors and determine whether these behaviors occur during the same period and are related to relationships among manufacturers. The definitions of these two codes are provided in Table 3. Then, we define a list of codes representing the typical characteristics shaping the development of dominant designs. First, we track the number and type of innovations launched on the market. Actually, these numbers and forms of innovation allow us to precisely determine whether a dominant design has emerged and the period related to the tipping point, as the number of disruptive innovations decreases after the selection of the dominant design, and incremental innovations are subsequently enhanced. Similarly, the development of standardization characterizes the phase after the selection of the dominant design. Then, we examine practices related to imitation and the protection of new innovation and the emergence of disruptive technologies (as defined in Table 3), as these events should foster the development of a new dominant design. Hence, in their synthesis, Fernández and Valle (2019) emphasized the importance of a high level of appropriability and, thus, protection for the firms to reap the benefits of the dominant design. Each category was divided into several subcategories (see Table 4 for an example).

Table 3. Categories from the literature review

\begin{tabular}{|c|c|c|}
\hline Objectives & Category & Justification/specifications \\
\hline \multirow{2}{*}{$\begin{array}{l}\text { Characterization of } \\
\text { coopetitive relationships }\end{array}$} & Cooperation & \multirow{2}{*}{$\begin{array}{l}\text { Those two categories refer to the definition of coopetition (Ritala \& Tidström, 20I4). In the interview, } \\
\text { we identify extracts describing cooperative and competitive behaviors among manufacturers (rivalry } \\
\text { criteria) and we check whether cooperative and competitive maneuvers took place at the same time by } \\
\text { examining the reference period (simultaneity criteria) (Gnyawali \& Park, 20I I). }\end{array}$} \\
\hline & Competition & \\
\hline \multirow[t]{2}{*}{$\begin{array}{l}\text { Determination of } \\
\text { whether a dominant } \\
\text { design emerged }\end{array}$} & Innovation & $\begin{array}{l}\text { Throughout the technological development cycle, firms innovate. Before the selection of a dominant } \\
\text { design, numerous product innovations are launched on the market (Abernathy \& Utterback, 1978). After } \\
\text { the dominant design selection, actors favor incremental innovations (Tushman \& Anderson, 1986) }\end{array}$ \\
\hline & Standard & $\begin{array}{l}\text { The establishment of a dominant design enforces standardization (Abernathy \& Utterback, 1978). The } \\
\text { deployment of coopetitive relationships has been proven to be a possible strategy for standardization } \\
\text { (Mione, 2009). The term 'standard' must be used to denote the technical specifications of the reference, } \\
\text { compatibility, and connectivity required for the proper functioning of products (Srinivasan et al., 2006). }\end{array}$ \\
\hline \multirow{3}{*}{$\begin{array}{l}\text { Description of the } \\
\text { factors shaping the } \\
\text { development of the } \\
\text { dominant design }\end{array}$} & Imitation & $\begin{array}{l}\text { The development of a dominant design supposes that actors converge on common choices. Imitation } \\
\text { practices are key in the development process of dominant designs, particularly actors who favor } \\
\text { competitive strategies (Cecere et al., 20 I5; Murmann \& Frenken, 2006). }\end{array}$ \\
\hline & Protection & $\begin{array}{l}\text { During the technology life cycle, firms may attempt to protect their technology from imitators to foster } \\
\text { their appropriability regime (Hurmelinna-Laukkanen \& Puumalainen, 2007; Shapiro \&Varian, 1998; Shibata, } \\
\text { 1993; Teece, 1986). Firms will use patents, secrets, and knowledge, and control human resources turnover } \\
\text { to avoid knowledge leakage (Hurmelinna-Laukkanen \& Puumalainen, 2007) and license their technology or } \\
\text { give access to their competitors to certain components to facilitate adoption (Ehrhardt, 2004). }\end{array}$ \\
\hline & Technology & $\begin{array}{l}\text { The development of a dominant design is linked to the integration of new technologies in products, } \\
\text { processes, or new services. A new technology can contribute to the development of a new dominant } \\
\text { design (Hekkert \& van den Hoed, 2004; Murmann \& Frenken, 2006). The dominant design could rely on } \\
\text { a single technology or on a combination of technologies (Christensen et al., 1998). Radical innovation is } \\
\text { often associated with the introduction of a new technology (Henderson \& Clark, 1990). Ritala and Sainio } \\
\text { (2014) showed that coopetition is negatively related to technology radicalness. }\end{array}$ \\
\hline
\end{tabular}


Table 4. Examples of coding

\begin{tabular}{|c|c|c|}
\hline Category & Subcategories & Examples of analysis units \\
\hline \multirow[t]{4}{*}{ Protection } & Patent & $\begin{array}{l}\text { I. Sometimes you come up with an idea that you put in a game and you don't change it but you may work on parts of } \\
\text { the machine around the new idea but you don't change the idea if you have a good one as we had to patent some } \\
\text { of it. [2/1962] } \\
\text { 2. One of the points we raised that was that we couldn't use the star rollovers, because Bally had come after Game } \\
\text { Plan to tell them that they had to cease-and-desist because they had the patent or the rights to those round star } \\
\text { rollovers. [I//979] }\end{array}$ \\
\hline & License & $\begin{array}{l}\text { I. Artwork also changed on Spy Hunter. Originally, I designed the game with an Elvis theme. The bonus lights } \\
\text { represented the push buttons on the front of a juke box. Each button pair represented a different Elvis song. Aligning } \\
2 \text { bonus lights played the indicated song. The only problem with that was that at the time, Bally had not secured the } \\
\text { Elvis license. [ } 5 / 1984] \\
\text { 2. The original intent was to have Star Wars as the first game licensed ... That was the richest agreement we had } \\
\text { done as a license for a pinball product, but not totally out of the realm of what I thought was realistic. I felt that all } \\
\text { bets were off and we had to. We needed this to help the platform. [I/I999] }\end{array}$ \\
\hline & Secret & $\begin{array}{l}\text { I. Williams' Banzai Run came out only two months later [after Bally's Blackwater I00]. They had no idea what I was } \\
\text { doing. At least I don't think they did. I don't know what kind of secrets got passed between the companies ... I think } \\
\text { it was just a coincidence they came out so close. I never suspected anything, but I was also never aware of copying } \\
\text { going on. [9/I988] } \\
\text { 2. There was an idea that electronics was the way to go. They did some electronic slot machines first. They were } \\
\text { basically poker machines if I remember correctly. That group spun off into electronic pinball machines. So the system } \\
\text { was developed more or less in the back room with no input from anybody. This was super, super secret. There were } \\
\text { only a handful of people who knew about it. That's the way the Bally system was designed. [27/I976-1978] }\end{array}$ \\
\hline & $\begin{array}{l}\text { Human resources } \\
\text { control }\end{array}$ & $\begin{array}{l}\text { I. When I was first starting out in design, it was industry policy that a designer could not put his name on a game. That } \\
\text { was to prevent another company from finding out who designed what game and hiring them away from their current } \\
\text { company. That was archaic thinking. In fact, literally within hours of a new game being placed at a test location, } \\
\text { everyone in the design industry knew who designed what game and what features were on it. [5/I974] }\end{array}$ \\
\hline
\end{tabular}

The contents of the different texts used were segmented into analysis units, which were then classified into the defined categories. The chosen analysis units were parts of sentences, whole sentences and even groups of sentences with a bearing on the same theme. The inference presumed to link the selected units to the respective categories is one of inclusion ( $X$ unit is an example of $Y$ category). The process of attribution of an analysis unit to a category occurs without interpretation. It is therefore a descriptive coding system (Huberman \& Miles, 2002). Certain quotations are used for illustrative purposes. In these quotations, the number before the slash indicates the ID number of the respondent (Table 2) and the dates after the slash indicate the time period covered or the reference year (see Table 4 for an example).

The protocol was tested by a process of double-coding (Weber, 1990). This process consists of confirming the definition of the analysis units and their classification into categories (inter-coder reliability) and dealing with any divergences.

\section{Results}

\section{The development and stabilization of a dominant design}

First, we assess whether the pinball industry experienced a dominant design. Consequently, we map the different innovations that occurred from 1930 to 2014. Figure 3 represents those different innovations and brings to light three phases. The first phase from 1930 to 1947, which corresponds to the era of ferment, encompasses 15 innovations, and a majority of those innovations have been integrated into the dominant design (although sometimes with a long time lag). The second phase (from 1947 to 1970) is the most productive in terms of innovation. However, several innovations were not successfully adopted into subsequent versions of pinball, which is a characteristic of the selection phase of the development of a dominant design. We consider that the selection phase ended in 1970 for two main reasons. First, after 1970, the number of product innovations declined significantly (0.27 per year, Table 5). From 1970 to 1980 (Figure 3), architectural innovations no longer changed the product design and no modular innovations were integrated into the dominant design (Banana flipper, Magna save ramp, Whirlwind spinner).

Then, as described in Figure 3, from 1970 onward, the 3" pinball and drop targets were generalized. Several experts of pinball consider that those two product innovations were very attractive for players and generated leads for those products. The 3" pinball offered a better control as well as drop targets, which really turned pinball into a game of skill (Shalhoub, 2004).

Thus, in 1970, the dominant design was established at three different levels: the global design of the product, the game board configuration, and the modules that constituted that board. The 'flipper,' the 'mushroom bumper,' the pediment, and 
Table 5. Types of innovations in the pinball industry

\begin{tabular}{|c|c|c|c|}
\hline & $\begin{array}{l}\text { Era of ferment } \\
1930 \rightarrow 1947\end{array}$ & $\begin{array}{l}\text { Selection phase } \\
1947 \rightarrow 1970\end{array}$ & $\begin{array}{l}\text { Incremental change } \\
|970 \rightarrow 20| 4\end{array}$ \\
\hline Architectural innovations & $9(60 \%)$ & $10(31.3 \%)$ & $2(16.7 \%)$ \\
\hline Modular innovations & $5(33.3 \%)$ & $17(53.1 \%)$ & $6(50 \%)$ \\
\hline Incremental innovations & | (6.7\%) & $5(15.6 \%)$ & $4(33.3 \%)$ \\
\hline Total & I 5 (0.88 per year) & 32 (1.39 per year) & 12 (0.27 per year) \\
\hline \multirow{4}{*}{$\begin{array}{l}\text { Number and type of innovations integrating the } \\
\text { dominant design }\end{array}$} & $9(60 \%)$ & $15(46.9 \%)$ & $4(33.3 \%)$ \\
\hline & Architectural: 5 & Architectural: 7 & Architectural: 0 \\
\hline & Modular: 4 & Modular: 7 & Modular: 4 \\
\hline & Incremental: 0 & Incremental: | & Incremental: 0 \\
\hline
\end{tabular}

the general use of targets, extra balls, and the 'match bonus' were the most typical elements of this dominant design (Figure 3). From 1970 to 2014 , the dominant design was not questioned. However, in the 1980s, the emergence of competition from video games compelled manufacturers to expand that design by integrating new features (Lane changes, Upper ramps, Animated toys...). Consequently, although the dominant design became increasingly more complex, no innovation deeply changed its functioning (Figure 3 and Table 5). This situation corresponds to the 'incremental change era.'

Figure 3 shows that throughout pinball history, manufacturers attempted to introduce novelties to differentiate their products; however, several of them were not incorporated into the dominant design. Similarly, our historical analysis demonstrates that manufacturers managed to exploit new technologies. Thus, from the beginning of the 1930s to the end of the 1940s, products were designed using mechanical processes. From the 1950s to the end of the 1970s, electromechanical technologies were favored. Electronics were broadly used in the 1980s, and videos were introduced in the 1990s. These new technologies resulted in the introduction of new modules and new game practices (i.e., electronics enhanced the development of multiplayer modes). The dominant design was enforced primarily by improvements to modules (e.g., digital display units are easier to manufacture, maintain, and repair than traditional mechanical counters).

\section{Innovations and firms' relationships}

In this section, we describe the three stages of the development of the dominant design, including the industry evolution, the outcomes in terms of innovation, and the types of relationships that were relied upon. To obtain a better understanding of the dynamic in terms of innovation, we identify for each of the three periods the number of architectural, modular, and incremental innovations (Table 5).

Each of these innovations has been developed by a unique manufacturer seeking to differentiate itself from its competitors.
Some have emerged on the market, have been imitated by competitors, and have integrated the dominant design. We have not identified any innovation from projects led by coalitions of manufacturers.

\section{Emergence and era of ferment (193 I-1947)}

Gottlieb pioneered the industry with the 'Baffle Ball' in 1931, and his success motivated other organizations to imitate his efforts (Colmer, 1976; Ruben, 20 I 8). In the mid- 1930s, approximately 150 pinball manufacturers operated in the United States as the industry was emerging, and most of these manufacturers were located in Chicago.

Innovation types. We computed I 5 main product innovations in the period, and a majority of them are architectural innovations (60\%). This period experienced only one incremental innovation. Actually, the main components were steadily incorporated into the dominant design, and they have rarely been modified afterward. For example, the plunger, which is a spring used to launch the ball, was first used in the 1930s. Similarly, the process called 'Tilt,' which prevents the machine from being raised, was also invented in the 1930s. The following quotation illustrates this point:

From a pinball standpoint, I said, the basic layout of the playfield should not be radically different from what the original was. [23/1940-1999]

The success of an innovation like the 'Baffle Ball' on the market showed that this industry conveys a competitive advantage to pioneers. Consequently, first entrants into the industry (such as Williams in 1943) sought to discover the best innovations to be launched. Thus, several innovations and product versions were developed without improving industrial processes, which is characteristic of the 'era of ferment,' during which there are a plethora of offerings.

Third parties play a major role in shaping innovations. Hence, operators requested a standardization of pinball machines' 
characteristics to facilitate the management of the machine fleet (anti-fraud systems, machine sizes, etc.). Thus, numerous innovations were proposed based on requirements from large operators and clients (owners of game rooms). Pinball tables with legs emerged in the mid-1930s and were incorporated due to solicitation from operators to increase the availability of machines (Jensen, 1979). The design of the 'Tilt' in 1932 stemmed from a requirement from operators who wanted to prevent players from cheating by shaking the machines excessively.

Even though a few main components of pinball were defined during this phase, in 1939, the industry remained unstructured. The American manufacturers were then requisitioned to participate in the war effort, and no dominant design existed.

Types of relationships between manufacturers. The era of ferment is characterized by mostly competitive relationships among manufacturers. We did not find any evidence of cooperation among manufacturers:

We never went out [with our competitors] to lunch. We never went out at night together. We stayed within our own little company. We never socialized with the employees of the other companies ... We never fraternized with other companies. $[13 / 1938]$

Furthermore, imitation between competitors is very common. As soon as a firm introduces a novelty on a model, its competitors try to offer it on their own machines. Thus, several companies enter the market with a strategy to imitate the pioneer's efforts (Colmer, 1976). Then, as described in Figure 3, several successful innovations were imitated by most manufacturers on the market and quickly became embedded in the dominant design: coil bumper, disc bumper, lights, plunger, Tilt ... The following quotation illustrates this point:

In those days, everybody was copying everybody else. It was the dog-eat-dog days. One time Jimmy came to about half a dozen of us guys, and he says, 'I'm going to get a game in here at five o'clock. I want you to copy it, but I have to get it out of here before dawn'. So when the game came in, we divide it up. Each one of us got a little section of this game to copy. We built it during the night, and by morning we had a copy of that game before we shipped the other one out at dawn. [13/ 1937]

Simultaneously, manufacturers were aware that they had to establish relationships with third parties to facilitate adoption, as they faced an unfavorable environment. Actually, manufacturers had to address resistance from the puritanical, social, and cultural establishments, and from legal representatives (Ruben, 20 I8). In the United States, pinball regulation occurred at three levels: federal, state, and local. Pinball bans were implemented in cities such as Washington DC (1936) and New York City (1942). The pinball industry was thought to be controlled by the mafia and to promote illegal gambling, which would lead to corruption.

\section{Selection phase (1947-1970)}

The industry continued to experience significant growth after the Second World War. Whereas several product innovations were developed between 1947 and 1970, main options were selected by all manufacturers, and the designs began to converge.

Innovation types. In 1947, the first flipper was designed by Gottlieb for the Humpty Dumpty game. This innovation was quickly adopted by the industry, as a player could exercise some control of the ball using this mechanism. As soon as 1948, eight other manufacturers were selling machines that integrated that accessory.

The selection phase witnessed numerous innovations than the other phases ( 1.39 per year; Table 5). Modular innovations were particularly represented (53.8\%). This observation indicates that the overall design of pinball machines was still evolving substantially. However, manufacturers were progressively stabilizing certain components and orienting their efforts into changing modules of the design without transforming the whole concept. A major shift occurred as the enthusiasm of players for new models that offered increasingly more innovations led manufacturers to integrate complex electromechanical components.

Types of relationships. This phase is characterized by coopetitive relationships among manufacturers. Actually, as the industry began to stabilize, employees of the competitive manufacturers developed individual relationships. They knew each other and exchanged key resources such as parts of machines, knowledge and information about the latest games. The following two quotations illustrate this point:

Forgetting about the very early days in the ' 30 s and ' 40 s, there was much more of a congenial atmosphere. There were, after all, family businesses and the friendly rivalries endured. I still remembered Sam Gensberg being on the phone ... calling Bally to get some parts for a new Chicago Coin game. They had run short of something and it wasn't unusual for this type of request to be made by any of the companies. Everybody was willing to give each other a helping hand... [1/1950s-1960s]

If you look back to what I consider the old days of pinball there was almost a friendly competition between Bally and Williams. In some ways, we helped each other. We would send our latest game over to Williams for evaluation and they would send their games to ... There was this place called Round Robin, which was a restaurant more or less in between Chicago Coin, Gottlieb, Bally, and Williams. It was not far from any of them. That seemed to be the pinball meeting place: neutral territory where people would go to have lunch or drink after work ... It was a different environment than you would ever see now, or what would be allowed now, with all the non-disclosure agreement and stuff. [27/1965-1970] 
As depicted in these two verbatim quotes, the social component of the relationship prevailed over business objectives. In 1951, the US Congress forbade the manufacture, sale, use, ownership, and maintenance of machines that enabled gambling (Colmer, 1976). The primary manufacturers were forced to legitimatize their activities and locate new sale outlets (notably in Europe). The first actions taken by manufacturers involved developing a community to set up their own institution. Harry Williams (founder of Williams Manufacturing) established the Coin Machine Institute to educate the public about pinball and demonstrate that it was just an amusement game. Manufacturers also played an active role in the development of the Coin Machine Industries Inc., which was a professional association organized to preserve automatic game manufacturers. Furthermore, pinball manufacturers engaged in numerous public relation activities with other associations, such as The Amusement and Music Operators Association, which was a lobbying association representing operators. In the 1960s, Gottlieb decided to contract with Rufus King to facilitate the permit of amusement pinball. King was an attorney who also often represented a number of pinball manufacturers (in particular Williams).

Numerous innovations were developed by manufacturers to bypass legal restrictions and to demonstrate that pinball was a game of skill that did not involve gambling. For example, the use of a 'match' bonus feature in pinball games (which allowed a player to win a free game by chance) was not accepted in certain states in the United States because lawmakers associated pinball closely with gambling. In 1960, Gottlieb proposed new pinball machines that allowed skillful players to win extra balls for certain sequences (Add-aBall Pinball, 1960) and receive extra play time as a result. However, pinball machines were forbidden in most American cities (particularly in New York, Los Angeles, and Chicago) until 1976.

Yet, those relationships were at the same time characterized by fierce competition.

There was a very strong competition between everybody. It's almost like a sport where you have teammates, but the teammates are also competing against each other. Who can be the fastest? Who can be the most agile? And it was the same in pinball. Everybody wanted to be the best. [27 / 1965-1970]

Thus, the success of a new concept often resulted in an overbid by competitors. For example, in 1962, Williams launched 'Vagabond,' the first pinball machine to use targets that could 'drop.' Because this model was successful, competitors imitated that accessory and widely deployed its usage. The following quotation made by the inventor of those targets who worked at Williams illustrates this situation:

I had an idea that if I could hit a target and it disappeared, it would be exciting to know that you might have accomplished something unusual. If the target would come up and for whatever reason have some kind of scoring, and when you hit it, it went down. I decided it was a good way to do it with a single target. Gottlieb then came up with 2, 3, 4, 5 and 10 drop targets and they did a terrific job with that feature. [2/1962]

During this phase, intellectual property rights (IPR), human resources control, and secrets were largely used to protect against imitators. However, our historical analysis of primary novelties introduced by manufacturers demonstrates that the appropriability regime was weak. Typically, only a few months passed between the emergence of a successful innovation and its massive (adaptation and) adoption by competitors. There are numerous examples of this same pattern. For example, in August 1968, Williams launched three-inch flippers to replace the standard two-inch flippers. From the 1970s onward, all manufacturers adopted these new dimensions because they were popular with players.

The goal of maintaining a competitive advantage over competitors while cooperating with them leads to paradoxical choices. At Gottlieb, some inventions (like the flipper in 1947) are not patented. Moreover, when competitors violate a patent, no lawsuit is envisaged!

We were concerned that someone else comes out with a flipper game ahead of us. We wanted to be the first with it. We had a long run of that game. We built 6,500 of that first flipper game. We enjoyed that long run. Then the others copied us. Gottlieb could have patented the flipper but he didn't ... There's only one thing that I know for sure he patented, which was my bumper switch ... Despite filing for the patent, everybody started using that switch. Didn't Gottlieb go after those violated the patent? No, we just didn't care. Dave was that way; he didn't care. Dave was a gentleman. [13/1947]

Our results indicate that coopetition allows the gradual selection of options and the formation of a dominant design. The cooperative component of relationships enhances the development of the dominant design by facilitating the convergence of what would be accepted as a new pinball. Competition also enhances convergence of options, as it speeds the adoption of successful features.

\section{Era of incremental change (1970-20|4)}

In 1976, the New York City Council finally allowed pinball games in the city. This ruling set a precedent and allowed for the rapid growth of pinball machines across the United States. Electronic pinball games were introduced in the second half of the 1970s.

Pinball manufacturers continued to experience high turnover in spite of the emergence of video games at the beginning of the 1980s. However, that time period ultimately led to the decline of the pinball machine industry. 
Innovation types. This period is characterized by the lowest number of innovations (0.27 per year; Table 5). Modular innovations and incremental innovations by far outnumbered architectural innovations (83.3\% vs. 16.7\%; Table 5). No architectural innovation integrates the dominant design. This demonstrates that the design is stabilized, and innovations mainly aim at reinforcing it. It also highlights the inability of manufacturers to radically reconsider previous choices to face new challenges, such as competition from the video game industry.

Types of relationships. Since 1976, pinball has been legal in the United States. Manufacturers can therefore benefit from a strong growth in their domestic market. They develop skills in electronics and increase their efforts to protect their innovations. During this phase, intellectual property rights (IPR), human resources control and secretive ways are still largely used to protect against imitators (see Table 4). Table 6 presents the distribution of patents filed by manufacturers since 1976. Even in this 'incremental change' phase, there is a significant use of patent filing. Williams seems to be filing significantly more patents than its competitors. Notably, however, 38 patents were filed by this manufacturer between 1995 and 1999 and concern the 'Pinball 2000 project' (machine combining pinball and video).

These patent filings sometimes resulted in lawsuits between competitors:

Are you familiar with the lawsuit that Bally had against Gottlieb? ... Along the way, Bally took a look at our system. I suppose Williams joined in on it, but I think Bally was the big one. They sued us for infringement on their electronic design. I was involved a lot in the deposition processes in which the lawyers wanted to pick our brains and find out whether there were any grounds for which Bally could sue us and make us penalties, royalties, or whatever. [31/1980]

Manufacturers also competed for contracts with renowned designers. Many of these designers were considered key resources, and manufacturers attempted to control the flow of information (see Table 4 for an illustration).

Table 6. Distribution of patents filed by manufacturer since 1976

\begin{tabular}{lcc}
\hline Manufacturer & Period & Number of patents \\
\hline Bally & $1976 \rightarrow 1988$ & $19(1.6$ per year $)$ \\
Gottlieb & $1979 \rightarrow \mid 994$ & $22(1.5$ per year $)$ \\
Williams & $1979 \rightarrow \mid 999$ & $88(4.4$ per year $)$ \\
\hline
\end{tabular}

N.B. It was not possible to retrace the exhaustive list of patents filed by pinball manufacturers before 1976.
However, our analysis demonstrates that the appropriability regime is still weak during this phase. The case of the 'Xenon' pinball machine, which was launched in December 1980 by Bally, is particularly informative. This machine included numerous innovations that were successful at the beginning of the 1980s: multi-level playfield, multi-ball game, and digital voices. The development of this model shows that manufacturers closely monitored the activities of their competitors to detect novelties and integrate them, even if it meant altering current projects. The following comments by a project manager describe this environment:

Bally's marketing department had heard of a competitor's talking game ...The decision was made to one-up the competition by utilizing a female's voice, as dictated by the artwork ... So now Bally had a game with a multi-level playfield, great artwork and great sounds. Then, Bally's marketing department heard that a multi-ball game was planned for release by a competitor. Well, Bally couldn't be beaten at their own game of one-upmanship. Bally wanted to sell a multi-ball game also ... Within hours, Xenon was transformed into a multi-ball game. [5 / 1979]

Two factors limited the IPR. Certain design choices could not be protected, and retro-engineering practices that could bypass patents were widespread. For example, in 1990, the Japanese arcade game manufacturer Data East first introduced the electronic pinball machine with the Robocop model. Thus, Data East was a new entrant in the sector (it had first proposed the model in 1987). Data East expected to benefit from its competences in electronics to develop innovative models. However, Williams bypassed the patent and launched a similar innovation on its own machines in 1992. The following quotations illustrate the role of retro-engineering practices and the difficulties in patenting certain mechanisms:

No, no, in fact almost everything that I itemized had some type of patent protection, some type of design protection, so it wasn't as if Game Plan could automatically go to the vendor who was supplying flippers to Gottlieb and say: "Hi, we would like to order flippers as well." It was a question of really going back and doing, I guess for lack of a better word to describe it, development from the ground up ... The way that the housing underneath was, what the mechanical parts were in terms of bracketing and so on, had to be somewhat unique. [1/1977]

[This mechanism] was a good feature. It was cool. But we were never able to patent it because of the language in the patent application. There was a lot of prior act, other features in other games, other mechanisms that were already patented. Many features were similar to this game in how they worded, not how they operated and so we couldn't be granted a patent. We tried twice and were denied twice. [28/1987] 
This weak appropriability regime prompted Gottlieb to waive patents during the 1970s, as shown in the following quote?

"All the manufacturers were keenly aware of what the others were doing in the industry because we were all trying to produce a product that would catch the fancy of the players and make more money." Dave Gottlieb didn't pursue the patent track to get exclusive use of any of his company's developments. He felt that as long as he got the first benefits of an idea, he didn't mind others copying it. His favourite quotation on that was "Imitation is the most sincere form of flattery." [Alvin Gottlieb, in Shalhoub, 2004, p. 21/1970s]

At the same time, manufacturers continue to cooperate during this phase, at least until the mid-1990s. They sought to collectively answer operators' solicitations to enhance their ability to maintain and repair machines (spare parts that were common to several models, standardization of maintenance processes, etc.).

I was working on games simultaneously for a couple of different, competitive companies. But everybody knew they could trust me. I was going to give them feedback that was open and honest ... For commercial operation, one of the keys concerns is "If I need a replacement part, where do I get it from?" ... I produced an amazing amount of mailings highlighting upcoming games, giving that operator/location owner whatever type of information was necessary and important such as how to operate and set up their games... By the same token there were different times, where many personal relationships became prioritized over professional secrecy, and maybe some things were shared in a way that they shouldn't have been. The net result was that you saw some striking similarities between competitive products at various points in time. It's a very fine line to tread. [I/ 1970s-1980s]

From the mid-1990s onward, relationships between manufacturers and operators deteriorated. Operators experienced a strong drop in demand from players and tried to renew their offerings by introducing electronic games suppliers (notably Japanese suppliers). For several decades, the relationships between operators and manufacturers were quite balanced because the former had key resources but no alternative suppliers for machines. However, the advent of video games considerably decreased the power of pinball manufacturers. Since the development of video games, pinball manufacturers had only one ambition: to regain the operators' confidence by proposing machines that better suited their requirements. Digital voices were added to enhance the attractiveness of pinball machines in arcade rooms. Certain manufacturers changed the size of their machines to become more similar to the video game console

\footnotetext{
2. In the early 1970s, health problems forced David Gottlieb to stop working. He died in 1974. Obviously, his successors at the head of the company resumed the filing of patents as shown in Table 6.
}

in arcade rooms (e.g., Williams with the 'Pinball Circus' prototype in 1994). Other manufacturers increasingly used animated characters or proposed models inspired by Foosbal or Bowling (e.g., 'Strikes n' Spares' from Gottlieb in 1995). Conversely, certain innovations promoted by manufacturers failed to achieve success in the market due to a lack of support from operators. The following two quotations illustrate this point:

The thing that most people don't understand about our business is that these are money-making devices. Their primary function is to make money for the operator. We don't just build things for players; we build things for a whole chain of command ... The operators in our business have a long memory. When you show them something (like this), they will say, "that has been tried before. It didn't make me a whole lot of money, why is it going to make me money now?" [16/1980-2010]

I thought that pinball machine cabinets had not changed in fifty years, or however long they had been around, and I wanted to design a new, modern, contemporary cabinet for pinball games ... I put the cabinet on a pedestal (there were no legs) to help it look more contemporary and modern... [But] operators did not care about cabinet designs; they just wanted to know how much money the game took in. It was hard to justify spending money on the cabinet. [9/1979]

Williams attempted alone to design models that integrated videos ('Pinball 2000'). In its latest projects, Williams was obsessed with secrecy at a level that had not previously been observed in the industry (Maletic, 2010).

Secrecy was critical to ensuring that Revenge from Mars make as big a splash as possible when it hit the market. Williams also wanted to keep their plans secret from their competitors to keep them from copying the new design. Williams even farmed out parts to multiple suppliers so that no one vendor saw more than a single piece of the puzzle. [23 / 1998-1999]

Those numerous examples demonstrate a lack of cooperation among manufacturers, which were attempting to individually find solutions to market decline. Relationships with third parties were also harmed. The necessity of maintaining good relationships with operators enticed manufacturers to invest in the development of new functionalities, in spite of the potential for such advances to damage the value proposition for others. Actually, numerous product innovations disturbed small operators (maintenance requiring new skills), location owners (revenue uncertainty generated by a radically new machine), and players (rules were increasingly specific to each machine). The following two quotations illustrate this point:

Let's accept the fact that if an operator or location owner needed to change a light bulb but there was a ramp with ten screws 
needing to be loosened, that it became counter-productive to operate pinball machines... [1 / late 90s]

Pinball lost a market of players because of their technologically enhanced games. The machines went a little haywire with their toys and all the different things they felt had to be on a game. [20/1990-2000]

Our historical analysis demonstrates that the relationships among the five manufacturers have been based on coopetition since the mid-1940s. Manufacturers were simultaneously competing while cooperating. The need to differentiate products to sell pinball machines to operators led manufacturers to innovate and quickly imitate successful competitors, which in turn amplified competition. Simultaneously, cooperation resulted from the necessity to address common threats and collectively respond to customer and partner demands.

Consequently, the two necessary conditions to qualify a situation as coopetitive are present: competition and cooperation occur concurrently (simultaneity criteria), and firms maintain relationships based on horizontal competition (rivalry criteria). Figure 4 summarizes the key points of the results and presents the different phases of the process.

\section{Discussion}

This section addresses the contributions of this research to the literature on dominant design and proposes a discussion of the results obtained from the historical analysis concerning absorptive capacity and appropriability regime. Finally, we develop some implications for managers.

\section{Contributions to the literature on dominant design}

The analysis of the history of the pinball machine industry demonstrates that in specific contexts, characterized by external threats and a high level of power of third parties, the dominant design is neither imposed by a single organization nor emergent from a collective strategy.

Competition and collaboration occurred simultaneously and on a single level of the value chain. To better comprehend that specificity, we use the image of cake-sharing from Nalebuff, Brandenburger, and Maulana (1996).

In a situation of coopetition, a firm competes successfully for its slice of the 'added value cake' and simultaneously seeks to ensure that the cake grows larger. In most studies regarding technological development and standard warfare, firms agree

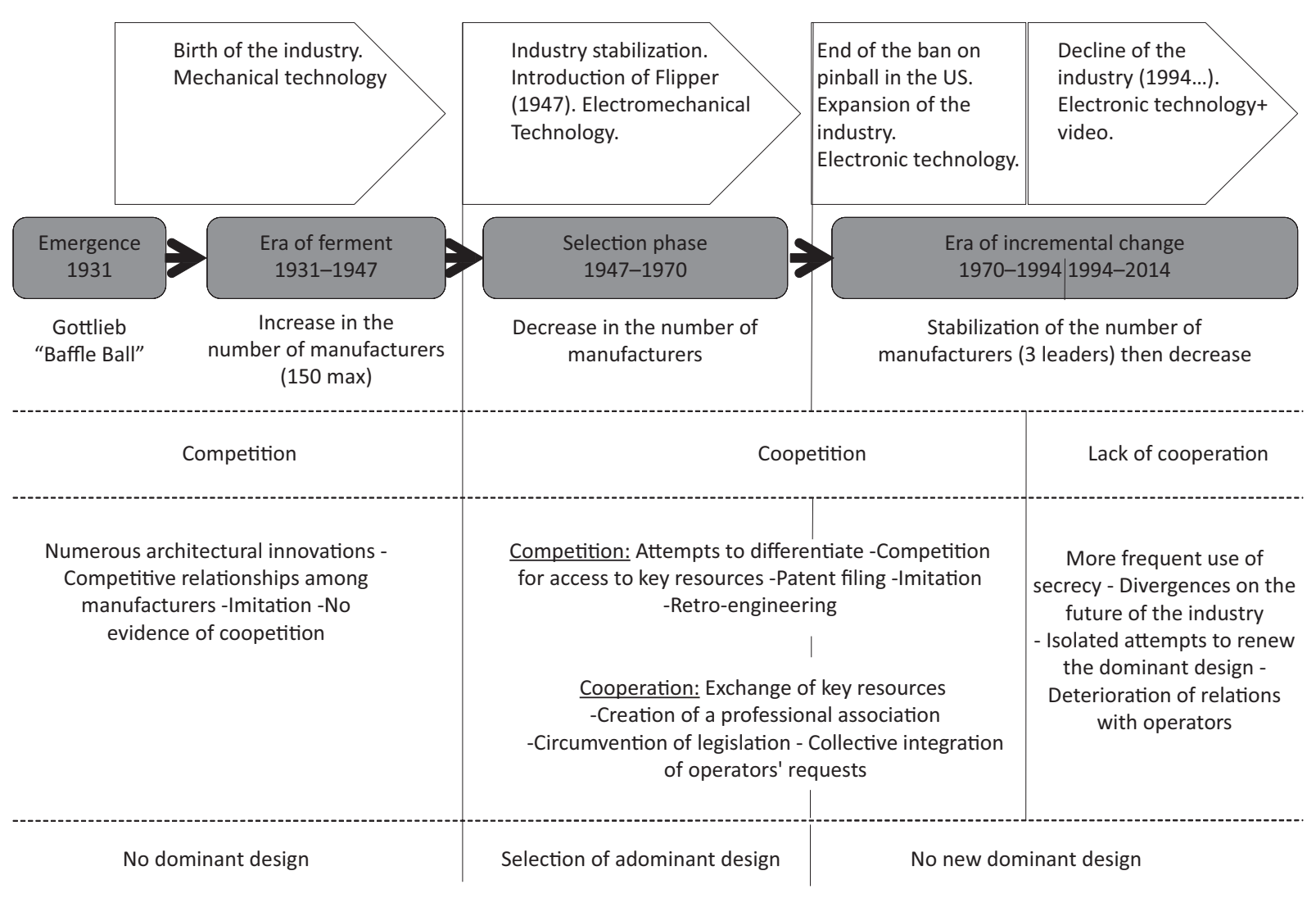

Figure 4. The development of a dominant design in the pinball industry: a synthesis 
on the cake recipe (in t0) and then attempt to obtain the largest slice of cake (in $\mathrm{tI}$ ). In particular, studies have demonstrated that the emergence of a standard can result from co-integration alliances (Dussauge \& Garrette, 1999) that are created by firms to define technical specifications and that allow for competition as the product is distributed (Rosenbloom \& Cusumano, 1987; Shibata, 1993). However, if the simultaneity criterion is considered, those agreements are not fully based on coopetition. In the pinball machine industry case, certain competitive companies operated in isolation to define the best recipe. Thus, these organizations integrated new ingredients (innovations) and simultaneously learned from competitors' ideas. This process - which includes imitation and innovation - resulted in a 'unique recipe,' which was collectively conceptualized from individual efforts.

The literature concerning dominant designs focuses on either 'competitive' or 'collective' strategies. In this research, we demonstrate that using only these two relational logics to understand firm actions is insufficient. Firms can cooperate and compete simultaneously to impose a dominant design. This is a significant contribution. To the best of our knowledge, very few researchers have analyzed the consequences of coopetitive relationships in the context of the formation of a dominant design. Prior studies have demonstrated that the need to develop product compatibility often results in coopetitive behaviors, specifically when there are network externalities (Ritala, 2012; Yami \& Nemeh, 2014). However, these prior studies have frequently defined coopetition as an alliance among competitors, which is a (perhaps overly) broad definition. Thus, it is impossible to check whether the situations studied respect the simultaneity criteria.

Those relationships impact innovative output. Thus, throughout the technological cycle, four types of innovation can be distinguished (Henderson \& Clark, 1990). The characteristics of innovation depend on the phase in which it is anchored (Abernathy \& Clark, 1978; Tushman \& Murmann, 1998; Murmann \& Frenken, 2006). By identifying coopetitive relationships during this cycle, our historical perspective allows renewing analysis of the influence of coopetition on innovation. The impact of coopetition on innovation remains controversial (Fernandez et al., 20l8). Previous scholars found a positive, neutral, or negative impact of coopetition on product innovation (Arranz \& Arroyabe, 2008; Gnyawali \& Park, 2009, 201 I; Nieto \& Santamaría, 2007; Santamaria \& Surroca, 201 I; Ritala \& Hurmelinna-Laukkanen, 2009). Recent studies, including radicalness as a moderated variable, also obtained mixed results (Bouncken \& Fredrich, 2012; Bouncken, Fredrich, Ritala, \& Kraus, 2017; Jakobsen \& Steinmo, 2016; Ritala, 2012; Yami \& Nemeh, 2014). However, those works do not contextualize innovations into the different phases of technological development in which they may occur.

During the first phase of pinball development (era of ferment, 1930-1947), no coopetitive behaviors were identified.
The second phase of selection (1947-1970) was characterized by a balanced coopetition (Bengtsson \& Kock, 2000; Yami, Chappert, \& Mione, 20I5) and led to numerous architectural and modular innovations (84.4\%; Table 5). During that period, the number of innovations was the highest ( 1.39 per year). After the selection of the dominant design (Era of incremental change, 1970-2014), the number of architectural innovations decreased significantly (16.7\%), whereas the number of incremental innovations increased significantly (33.3\%). The number of innovations per year was the lowest ( 0.27 per year). Those results are coherent with Anderson and Tushman's (1990) as well as Murmann and Frenken's (2006) work: the industry entered a phase of incremental changes, which did not challenge the design but reinforced it.

From the 90s onward, relationships among manufacturers worsened. Competitive coopetition (Bengtsson \& Kock, 2000; Yami et al., 20I5) was the predominant mode of strategic behaviors. No architectural innovation was incorporated into the dominant design. Individual attempts to renew the design emerged but none succeeded (Table 5). Thus, our findings contribute to the debate on the impact of coopetition on innovation. We show that coopetition can be fruitful for incremental, modular, and architectural innovations. However, coopetition does not entice actors to introduce a disruption to change the dominant design. In the case that we studied, actors were trapped in the dominant design and tried to improve it with competitive technologies but did not manage to create a radically new design.

\section{Absorptive capacity and appropriability regime: Lessons from the historical analysis}

In the dominant design literature, the results of the strategic maneuvers depend on the appropriability regime (Teece, 1986) and the absorptive capacity (Cohen \& Levinthal, 1990). In a context of coopetition, the firm's ability to acquire knowledge from external sources and to protect its innovations against imitation is relevant in increasing the innovation outcomes of collaborating with its competitors (Ritala \& Hurmelinna-Laukhanen, 2013).

In our study, the ability of manufacturers to regularly and quickly integrate new technologies (mechanical, electrical, electronic, digital, and video technologies) to strengthen the dominant design demonstrates a strong absorptive capacity. However, this study highlighted that the pinball machine industry was characterized by a weak appropriability regime (e.g., difficulty protecting design components, patent infringements, and non-exclusivity of key resources, such as designers). Hurmelinna-Laukkanen and Puumalainen (2007) differentiate among five main mechanisms to strengthen the appropriability regime. However, in the studied case, those mechanisms did not successfully lead to value appropriation. Tacit knowledge 
was difficult to protect as several key individuals (particularly designers) regularly changed employers or were working simultaneously for several manufacturers. Mechanisms of institutional protection (more particularly patents) provided a weak protection as shown by short imitation delays. Exclusive exploitation licenses (with movie theaters, music stars...) were signed. However, as plenty of licenses were agreed upon, they did not represent a scarce asset. As each manufacturer imposed a worldwide renowned brand, none of them managed to gain a competitive advantage. Human resource management did not permit the protection of key human assets. Technical protection tools (passwords, specific protocols...) were not broadly used as operators imposed standardization (such as operating instructions, maintenance, and stocks of spare parts). Finally, the continuous development of new products to take advantage of a time-based advantage provided deceptive results. The imitation timeframe was often short due to retro-engineering practices.

Thus, our results are not consistent with the findings of Ritala and Hurmelinna-Laukkanen (2013), who analyzed absorptive capacity in a coopetitive environment and identified the positive impact of a high appropriability regime, which is not present in our research.

In spite of a weak appropriability regime, pinball machine manufacturers benefitted from coopetitive relationships. American manufacturers that existed in the mid-1940s experienced steady growth and became worldwide leaders. European manufacturers (the Italian Zaccaria and the Spanish Recel) remained marginal participants in the industry, although they had access to a substantial domestic market. Even the Japanese manufacturers, Data East and Sega, which were leading innovators in electronic technology development, did not challenge the Chicago manufacturers' competitive positions. Consequently, coopetitive relationships allowed market development, innovation, and economic performance over a long time period, and protection against common rivals. These observations align with the conclusions of Ritala (2012).

However, in the literature focusing on the development of innovation through coopetitive relationships, most researchers identify formal agreements between firms. These agreements usually lead to the creation of joint ventures and joint patents (Gnyawali \& Park, 20l I). One of the key success factors is the identification of the right structure to achieving common innovation projects (Fernandez et al., 2018). In the Pinball industry, the coopetitive relationships were developed without a formal agreement among the manufacturers and implementation of intermediation structures. Studies in other contexts should be conducted to assess the scope of this result.

However, from the perspective of pinball machine manufacturers, the 1990s were characterized by a decline in interest and an increase in competitive behaviors. Thus, the nature of coopetitive relationships changed (Sanou, Le Roy, \& Gnyawali,
2016), and this had impact at the industry level. Actually, renewed efforts were undertaken in multiple directions but were less concerted and deliberate. Thus, our analysis demonstrates that as relationships became more competitive, the situation for all pinball machine manufacturers deteriorated. As long as coopetitive relationships were maintained, manufacturers were able to grow. Thus, as described by Bengtsson and Raza-Ullah (2016), we considered coopetition as a continuum between purely competitive and cooperative relationships. Whereas during the first periods of our study, actors had aligned their expectations and focused on legitimizing and increasing the adoption of their activity, during the last period, they had a different set of expectations. The rules and goals of competition were reformulated (Dorn et al., 2016), which eroded the overall benefits that actors could draw from their relationships. However, this observation should be tested in other contexts because we cannot assess whether more-coopetitive relationships would have enabled the pinball machine manufacturers to survive.

\section{Conclusion}

The aim of this research was to contribute to the current literature regarding the development of a dominant design using the coopetition framework to obtain an improved understanding of the interplay among actors engaged in this development. We identify how coopetitive relationships may lead to the development of a dominant design. Our historical analysis regarding the development of a dominant design in the pinball machine industry details the characteristics of that dominant design (which occurred from the 1970s onward) and demonstrates that it results from a coopetitive process. Because manufacturers differentiated their offerings, innovated, and simultaneously imitated others, increased competition resulted. Simultaneously, external threats and the need to collectively respond to clients and partners prompted the manufacturers to cooperate with one another.

Our study shows that firms might benefit from collaborating with competitors to create a dominant design, even with a weak appropriability regime. Thus, this case study suggests that as a theoretical framework, coopetition allows for the development of new perspectives for research regarding technological cycles, particularly with respect to the selection of dominant designs. Our observations also confirm or invalidate conclusions from previous works on coopetition strategies.

However, numerous questions remain. First, the observed industry has specificities that may limit the generalization of our results. These limitations include the requirement for participants to legitimize their activity and a weak appropriability regime. Studies in other contexts should be conducted to assess the scope of our results. Furthermore, our historical 
method did not allow us to study in detail how firms manage and organize their relationships (e.g., how pinball manufacturers and their managers dealt with antagonistic relationships). Certain authors have demonstrated that coopetition has an impact on organizational arrangements and on project structures (Bengtsson \& Kock, 2000; Fernandez et al., 20 I 8). Our a posteriori analysis did not allow us to produce results regarding 'coopetition management' (Le Roy, Fernandez, \& Chiambaretto, 2019). Future research may investigate these specific aspects of coopetition.

\section{References}

Abernathy, W. J. \& Utterback, J. M. (1978). Patterns of industrial innovation. Technology Review, 80(7), 40-47.

Akrich, M., Callon, M., Latour, B. \& Monaghan, A. (2002a). The key to success in innovation Part I: The art of interessement. International Journal of Innovation Management, 6(2), 187-206. doi: 10.1142/ SI363919602000550

Akrich, M., Callon, M., Latour, B. \& Monaghan, A. (2002b). The key to success in innovation part II: The art of choosing good spokespersons. International Journal of Innovation Management, 6(2), 207-225. doi: | 0.1 | 42/s | 3639|9602000562

Anderson, P.\&Tushman, M. L. (1990).Technological discontinuities and dominant designs: A cyclical model of technological change. Administrative Science Quarterly, 35, 604-633. doi: I0.2307/23935। I

Arranz, N. \& Arroyabe, J. C. (2008). The choice of partners in R\&D cooperation: An empirical analysis of Spanish firms. Technovation, 28, 88-100. doi: 10.1016/j.technovation.2007.07.006

Arthur, W. B. (1989). Competing technologies, increasing returns, and lock-in by historical events. The Economic Journal, 99(394), I I 6-I31. doi: $10.2307 / 2234208$

Astley, G. \& Fombrun, C. J. (1983). Collective strategy: Social ecology of organizational environments. Academy of Management Review, 8(4), 576-587. doi: I0.5465/amr. 1983.4284657

Batson, B.J. \& Bellgraph, B. B. (2008). Pinball passion. Playfield Productions. Bengtsson, M. \& Kock, S. (2000). 'Coopetition' in business networks To cooperate and compete simultaneously. Industrial Marketing Management, 29(5), 4I I-426. doi: I0. I 0 I 6/s00 I 9-850 I (99)00067-X

Bengtsson, M. \& Kock, S. (20I4). Coopetition - Quo vadis? Past accomplishments and future challenges. Industrial Marketing Management, 43(2), | 80-188. doi: | 0.10 | 6/j.indmarman.2014.02.015

Bengtsson, M., Kock, S. \& Lundgren-Henriksson, E.-L. (20।9). Coopetition research. Rooting and future agendas. In A.-S. Fernandez, P. Chiambaretto, F. Le Roy \&W. Czakon (Eds.), The Routledge companion to coopetition strategies (pp. 13-22). Abingdon: Routledge. doi: | 0.4324/978 | 3 | 5 | 85644-2

Bengtsson, M. \& Raza-Ullah, T. (2016). A systematic review of research on coopetition: Toward a multilevel understanding. Industrial Marketing Management, 57, 23-39. doi: I0. I 1 I6/j.indmarman.20।6.05.003

Bijker, W. E., Hughes, T. P. \& Pinch, T. (Eds.). (1989). The social construction of technological systems, new directions in the sociology and history of technology. Cambridge, MA: MIT Press. doi: I0.10 I7/s00257273000495 I6

Bouncken, R. B. \& Fredrich, V. (20I2). Coopetition: Performance implications and management antecedents. International Journal of Innovation Management, | 6(5), | 250028, I-28. doi: | 0. I |42/s | 3639 | 96 | 2500284

Bouncken, R. B., Fredrich, V., Ritala, P. \& Kraus, S. (2017). Coopetition in new product development alliances: Advantages and tensions for incremental and radical innovation. British Journal of Management, 29(3), 39|-4 |0. doi: |0. I | | |/ 467-855 |. |2213

Bouncken, R. B., Gast, J., Kraus, S. \& Bogers, M. (2015). Coopetition: A systematic review, synthesis, and future research directions. Review of Managerial Science, 9(3), 577-60 I. doi: I0. I007/s I | 846-0 I5-0 I 68-6

Brandenburger, A. M. \& Nalebuff, B. J. (1995, July-August). The right game: Use game theory to shape strategy. Harvard Business Review, pp. 57-7I. doi: I 0. I 01 6/0024-630 I (95)90326-7

Castaldo,S., Möellering, G., Grosso, M.\& Zerbini,F.(20 I 0). Exploring how thirdparty organizations facilitate coopetition management in buyer-seller relationships. In S. Yami, S. Castaldo, B. Dagnino \& F. Le Roy (Eds.), Coopetition: Winning strategies for the 2 I st century (pp. | |4|-165). Cheltenham: Edward Elgar Publishing. doi: 10.4337/978 | 84980724I.00016

Cecere, G., Corrocher, N. \& Battaglia, R. D. (2015). Innovation and competition in the smartphone industry: Is there a dominant design? Telecommunications Policy, 39(3-4), 162-175. doi: 10.1016/j. telpol.2014.07.002

Chabaud, D. \& Germain, O. (2006). Re-using qualitative data in management science: A second choice? M@n@gement, 9(3), 191-213. doi: 10.3917/mana.093.0199

Chiambaretto, P. \& Dumez, H. (20 I 2). The role of bundling in firms' marketing strategies: A synthesis. Recherche et Applications en Marketing, 27(2), 9|-| 05. doi: I0.1 |77/205 | 5707| 202700205

Chiambaretto, P. \& Rigaud, E. (20।3). Coopétition, hétérogénéité des consommateurs et stratégies de ciblage. Journal of Social Management/Revue Européenne des Sciences Sociales et du Mangement, II, 98-131.

Choi, P., Garcia, R. \& Friedrich, C. (2009). The drivers for collective horizontal coopetition: A case study of screwcap initiatives in the international wine industry. International Journal of Strategic Business Alliances, I (3), 27I-290. doi: I0. I504/ijsba.20 I 0.030427

Christensen, C. M., Suárez, F. F. \& Utterback, J. M. (1998). Strategies for survival in fast-changing industries. Management Science, 44(12-part 2), S207-S220. doi: 10.1287/mnsc.44.12.s207

Cohen, W. M. \& Levinthal, D. A. (1990). Absorptive capacity: A new perspective on learning and innovation. Administrative Science Quarterly, 35(I), I28-| 52. doi: I0.2307/2393553

Colmer, M. (1976). Pinball an illustrated history. New York, NY: New American Library.

Cusumano, M. A., Mylonadis, Y. \& Rosenbloom, R. S. (1992). Strategic maneuvering and mass-market dynamics: The triumph of VHS over beta. Business History Review, 66 ( I), 5 I-94. doi: 10.2307/31 I7053

Czakon, W. \& Czernek-Marszatek, K. (2019). Trust in tourism dyadic and network coopetion. In A.-S. Fernandez, P. Chiambaretto, F. Le Roy \& W. Czakon (Eds.), The Routledge companion to coopetition strategies (pp. 83-92). Abingdon: Routledge. doi: I0.4324/978 I3 I 5 I 85644-8

Czakon, W. \& Dana, L. P. (2013). Coopetition at work: How firms shaped the airline industry. Journal of Social Management, I I (2), 32-6I.

Depeyre, C. \& Dumez, H. (20I0). The role of architectural players in coopetition: The case of the US defense industry. In S. Yami, S. Castaldo, B. Dagnino \& F. Le Roy (Eds.), Coopetition: Winning strategies for the 21st century (pp. 124-141). Cheltenham: Edward Elgar Publishing. doi: 10.4337/978|84980724|.00015

Dorn, S., Schweiger, B. \& Albers, S. (20।6). Levels, phases and themes of coopetition: A systematic literature review and research agenda. European Management Journal, 34(5), 484-500. doi: I0. I 1 I 6/j.emj.20 I 6.02.009

Dussauge, P. \& Garrette, B (1999). Cooperative Strategy. Competing Successfully through Strategic Alliances. Chichester: Wiley.

Dyer, J. H. \& Singh, H. (1998). The relational view: Cooperative strategy and sources of inter-organizational competitive advantage. Academy of Management Review, 23(4), 660-679. doi: I0.5465/amr. I998. 1255632 
Ehrhardt, M. (2004). Network effects, standardization and competitive strategy: How companies influence the emergence of dominant designs. International Journal of Technology Management, 27(2-3), 272-294. doi: I0.1504/ijtm.2004.003956

Fernandez, A.-S., Le Roy, F. \& Chiambaretto, P. (20।8). Implementing the right project structure to achieve coopetitive innovation projects. Long Range Planning, 5 I (2), 384-405. doi: I 0. I 0 I6/j.Irp.2017.07.009

Fernandez, A.-S., Le Roy, F. \& Gnyawali, D. R. (20I4). Sources and management of tension in co-opetition case evidence from telecommunications satellites manufacturing in Europe. Industrial Marketing Management, 43(2), 222-235. doi: 10.10 16/j.indmarman.2013.1 1.004

Fernández, E. \& Valle, S. (2019). Battle for dominant design: A decision-making model. European Research on Management and Business Economics, 25(2), 72-78. doi: 10.1016/j.iedeen.2019.01.002

Funk, J. L. (2003). Standards, dominant designs and preferential acquisition of complementary assets through slight information advantages. Research Policy, 32(8), | 325-134| doi: I0. I 0 |6/s0048-7333(02)00 I2 I-x

Garud, R. \& Karnøe, P. (2003). Bricolage versus breakthrough: Distributed and embedded agency in technology entrepreneurship. Research Policy, 32(2), 277-300. doi: 10.1016/s0048-7333(02)00100-2

Garud, R., Jain, S. \& Kumaraswamy, A. (2002). Institutional entrepreneurship in the sponsorship of common technological standards: The case of Sun Microsystems and Java, Academy of Management Journal, 45(I), 196-2 14. doi: 10.2307/3069292

Geroski, P.A. ( 1 995). What do we know about entry? International Journal of Industrial Organization, 1 3,42 I-440. doi: I 0. I 0 16/0 I 67-7187(95)00498-x

Glaser, B. \& Strauss, A. (1967). The discovery of grounded theory. Strategies for qualitative research. Chicago, IL: Aldine Publishing Company. doi: 10.1007/978-3-658-13213-2_59

Gnyawali, D. R. \& Park, B. J. R. (2009). Co-opetition and technological innovation in small and medium-sized enterprises: A multilevel conceptual model. Journal of Small Business Management, 47(3), 308-330. doi: | 0. I | | |/j. | 540-627×.2009.00273

Gnyawali, D. R. \& Park, B. J. R. (20II). Co-opetition between giants: Collaboration with competitors for technological innovation. Research Policy, 40(5), 650-663. doi: 10.1 01 6/j.respol.201 I.01.009

Gnyawali, D. R. \& Ryan Charleton, T. (2018). Nuances in the interplay of competition and cooperation: Towards a theory of coopetition. Journal of Management, 44(7), 25 I I-2534. doi: I0. I I 77/0 | 492063 I 8788945

Gnyawali, D. R. \& Song, Y. (2016). Pursuit of rigor in research: Illustration from coopetition literature. Industrial Marketing Management, 57, I2-22. doi: 10.10 | 6/j.indmarman.20 16.05.004

Hamouti, R., Robert, F. \& Le Roy, F. (20/4). Individual strategy, vertical cooperation or coopetition strategy: What is the best strategy for product innovation? Innovations, I (43), |35-|6|. doi: 10.39|7/ inno.043.0135

Heaton, J. (2004). Reworking qualitative data.Thousand Oaks, CA: Sage.

Hekkert, M. \& van den Hoed, R. (2004). Competing technologies and the struggle towards a new dominant design. Greener Management International, 47, 29-43. doi: 10.9774/gleaf.3062.2004.au.00005

Helms, M., Cook, H. \& Fisher, D. (1997). Pleasure machine, the history of pinball. New Video Images.

Henderson, R. M. \& Clark, K. B. (1990). Architectural innovation: The reconfiguration of existing product technologies and failure of established firms. Administrative Science Quarterly, 35(I), 9-30. doi: 10.2307/2393549

Huberman, A. M. \& Miles, M. B. (2002). The qualitative researcher's companion. Thousand Oaks, CA: Sage. doi: 10.4I 35/978|4I 2986274

Huhtamo, E. (2005). Slots of fun, slots of trouble. An archaeology of arcade gaming. In J. Raessens \& J. Goldstein (Eds.), Handbook of computer games studies (pp. 3-2I). Cambridge, MA:The MIT Press. doi: I0.1 I62/ leon.2007.40.2.207

Hurmelinna-Laukkanen, P.\& Puumalainen, K. (2007). Nature and dynamics of appropriability: Strategies for appropriating returns on innovation. $R \& D$ Management, 37(2), 95- | | 2. doi: I0. I I | |/j. |467-93 I0.2007.00460.x

Jakobsen, S. \& Steinmo, M. (2016). The role of proximity dimensions in the development of innovations in coopetition: A longitudinal case study. International Journal of Technology Management, 7/ (I/2), I00-I22. doi: I0.1504/ijtm.2016.077976

Jensen, R. (1979). What is Pinball? Amusement Review, 2, 3-4.

Joosten, J. (Ed.). (20I2). Pinball Magazine, I. Utrecht: Unigroove Publishing. Joosten, J. (Ed.). (20।3). Pinball Magazine, 2. Utrecht: Unigroove Publishing. Joosten, J. (Ed.). (20|4). Pinball Magazine, Special Issue. Utrecht: Unigroove Publishing.

Joosten, J. (Ed.). (20 I 5). Pinball Magazine, 3. Utrecht: Unigroove Publishing. Joosten, J. (Ed.). (20।6). Pinball Magazine, 4. Utrecht: Unigroove Publishing. Joosten, J. (Ed.). (20।8). Pinball Magazine, 5. Utrecht: Unigroove Publishing. Katz, M. L. \& Shapiro, C. (1985). Network externalities, competition, and compatibility. The American Economic Review, 75(3), 424-440. https:// www.jstor.org/stable/ I 8 | 480

King, J. L., Gurbaxani, V., Kraemer, K. L., McFarlan, F. W., Raman, K. S. \& Yap, C. S. (1994). Institutional factors in information technology innovation. Information Systems Research, 5(2), I 39-169. doi: 10.1 287/isre.5.2.139

Klepper, S. (1996). Entry, exit, growth, and innovation over the product life cycle. The American Economic Review, 86(3), 562-583.

Klymas, P. (2019). Organizational culture models of coopetitors. In A.-S. Fernandez, P. Chiambaretto, F. Le Roy \& W. Czakon (Eds.), The Routledge companion to coopetition strategies (pp. 117-127). Abingdon: Routledge. doi: I0.4324/978 I 3 I 5 I 85644- I I

Kœnig, G. (2004). Management stratégique. Projets, interactions \& contextes. Paris: Dunod.

Lee, G.K. (2007). The significance of network resources in the race to enter emerging product markets: The convergence of telephony communications and computer networking, 1989-200I. Strategic Management Journal, 28(I), 17-37. doi: 10.1002/smj.566

Liebowitz, S. J. \& Margolis, S. E. (1995). Path dependence, lock-in, and history. Journal of Law, Economics, \& Organization, I I ( I), 205-226. doi: 10.2139/ssrn. 1706450

Le Roy, F., Fernandez,A.-S. \& Chiambaretto, P. (2019). From strategizing coopetition to managing coopetition. In A.-S. Fernandez, P. Chiambaretto, F. Le Roy \&W. Czakon (Eds.), The Routledge companion to coopetition strategies (pp. 36-46). Abingdon: Routledge. doi: I 0.4324/978 I 3 I 5 I 85644-4 Maletic, G. (2010). Tilt, the battle to save pinball, the future of pinball. LLC.

March, J. (1991). Exploration and exploitation in organizational learning. Organization Science, 2( I), 7I-87. doi: 10.1287/orsc.2.1.71

Mariani, M. (2019). The role of policy makers and regulators in coopetition. In A.-S. Fernandez, P. Chiambaretto, F. Le Roy \& W. Czakon (Eds.), The Routledge companion to coopetition strategies (pp. 105- | 16). Abingdon: Routledge. doi: 10.4324/9781315185644-10

Mione, A. (2009). When entrepreneurship requires coopetition:The need for standards in the creation of a market. International Journal of Entrepreneurship and Small Business, 8(1), 92-109. doi: 10.1504/ijesb.2009.024I07

Murmann, J. P. \& Frenken, K. (2006). Toward a systematic framework for research on dominant designs, technological innovations, and industrial change. Research Policy, 35, 925-952. doi: I0. I0 I6/j.respol.2006.04.0 I I

Nalebuff, B. J., Brandenburger, A. \& Maulana, A. (1996). Co-opetition. London: Harper Collins Business.

Nieto, M. J. \& Santamaría, L. (2007). The importance of diverse collaborative networks for the novelty of product innovation. Technovation, 27(6), 367-377. doi: 10.10 I6/j.technovation.2006.10.00 I 
Peng, T. J. A., Yen, M. H. \& Bourne, M. (2018). How rival partners compete based on cooperation? Long Range Planning, 5 I (2), 35 I-383. doi: 10.10 | 6/j.Irp.2017.10.003

Ritala, P. (2012). Coopetition strategy - When is it successful? Empirical evidence on innovation and market performance. British Journal of Management, 23, 307-324. doi: I0.1 I I I/j. |467-855 I.201 I.00741.x

Ritala, P. \& Hurmelinna-Laukkanen, P. (2009). What's in it for me? Creating and appropriating value in innovation-related coopetition. Technovation, 29(12), 819-828. doi: 10.10 16/j.technovation.2009.07.002

Ritala, P. \& Hurmelinna-Laukhanen, P. (20।3). Incremental and radical innovation in coopetition - The role of absorptive capacity and appropriability. Journal of Product Innovation Management, 30 (I), I54-I69. doi: | 0. I | | |/j. | 540-5885.2012.00956.x

Ritala, P., Kraus, S. \& Bouncken, R. B. (2016). Introduction to coopetition and innovation: Contemporary topics and future research opportunities. International Journal of Technology Management, 7I(I-2), I-9. doi: 10.1504/IJTM.2016.077985

Ritala, P. \& Sainio, L. M. (20|4). Coopetition for radical innovation: Technology, market and business-model perspectives. Technology Analysis \& Strategic Management, 26(2), 155-169. doi: 10.1080/ 09537325.2013 .850476

Ritala, P. \& Tidström, A. (20|4). Untangling the value-creation and value-appropriation elements of coopetition strategy: A longitudinal analysis on the firm and relational levels. Scandinavian Journal of Management, 30(4), 498-5 15. doi: 10.1016/j.scaman.2014.05.002

Rosenbloom, R. \& Cusumano, M. (1987). Technological pioneering and competitive advantage: The birth of the VCR Industry. California Management Review, 29(4), 5 I-76. doi: 10.2307/4 I | 62 I 3 |

Rossignoli, M. (20। I). The complete pinball book (3rd ed.). Atglen: Schiffer.

Ruben, A. (2018). Pinball wizards, jackpots, drains and the cult of the Silber ball. Chicago, IL: Chicago Review Press.

Sanou, F. H., Le Roy, F. \& Gnyawali, D. R. (2016). How does centrality in coopetition networks matter? An empirical investigation in the mobile telephone industry. British Journal of Management, 27(1), 143-160. doi: |0.1 | | |/467-855 |.12132

Santamaria, L. \& Surroca, J. (20II). Matching the goals and impacts of R\&D collaboration. European Management Review, 8(2), 95-109. doi: |0.1 | | |/j. 1740-4762.201 1.01012.x

Schubert, C., Sydow, J. \& Windeler, A. (2013). The means of managing momentum: Bridging technological paths and organisational fields. Research Policy, 42(8), I 389- | 405. doi: I 0. I 0 I6/j.respol.2013.04.004

Shalhoub, M. (2002). The pinball compendium, 1, 1930-1960s. Atglen: Schiffer.

Shalhoub, M. (2004). The pinball compendium, 2, 1970-1981.Atglen: Schiffer.

Shalhoub, M. (2005). The pinball compendium, 3, 1982 to present. Atglen: Schiffer.

Shapiro, C. \& Varian, H. R. (1998). Information rules: A strategic guide to the network economy. Cambridge, MA: Harvard Business Review Press.

Shibata, T. (1993). Sony's successful strategy for compact discs. Long Range Planning, 26(4), I6-21. doi: 10.1016/0024-630 I (93)90053-i

Silverman, D. (2000). Doing qualitative research: A practical handbook. London: Sage.

Simon, H. A. (1962). The architecture of complexity: Hierarchic systems. Proceedings of the American Philosophical Society, 106, 467-482.

Smith, W. K. \& Tushman, M. L. (2005). Managing strategic contradictions. Organization Science, I 6(5), 522-536. doi: I0.1287/orsc. I050.0I 34
Soh, P.H. (20I0). Network patterns and competitive advantage before the emergence of a dominant design. Strategic Management Journal, 3 I (4), 438-461. doi: 10.1002/smj.819

Srinivasan, R., Lilien, G. L. \& Rangaswamt,A. (2006). The emergence of dominant designs. Journal of Marketing, 70(2), I- I7. doi: I 0. I 509/jmkg.70.2. I

Stake, R. E. (1994). Case studies. In N. K. Denzin \& Y. S. Lincoln (Eds.), Handbook of qualitative research (pp. 236-247). Thousand Oaks, CA: Sage Publications.

Stewart, D. (1984). Secondary research: Information sources and methods. Newbury Park, CA: Sage.

Suárez, F. F. \& Utterback, J. M. (1995). Dominant designs and the survival of firms. Strategic Management Journal, 16(6), 4I5-430. doi: 10.1002/ smj.4250160602

Sullivan, B., Jacobsen, C. \& Rickard, E. (2010). Special when lit. Steam.

Sydow, J., Windeler, A., Schubert, C. \& Möllering, G. (2012). Organizing R\&D consortia for path creation and extension: The case of semiconductor manufacturing technologies. Organization Studies, 33(7), 907-936. doi: | 0. I | 77/0 | 708406 | 2448029

Teece, D. J. (1986). Profiting from technological innovation: Implications for integration, collaboration, licensing and public policy. Research Policy, 15(6), 285-305. doi: 10. I 0 1 6/0048-7333(86)90027-2

Tellier, A. (2015). Le déclin des écosystèmes d'affaires: quelles leçons tirer de la chute des «trois géants de Chicago»? Revue Française de Gestion, 4 I (248), 23-39. doi: 10.3 I66/rfg.248.23-39

Tellier,A. (2017). Whatever happened to the 'great escape'? Lessons from the rise and decline of the pinball ecosystem. International Journal of Technology

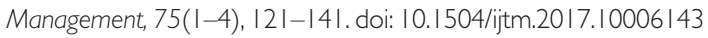

Tushman, M. L. \& Rosenkopf, L. ( 1992). On the organizational determinants of technological change. In B. Staw \& L. Cummings (Eds.), Research in Organizational Behavior, Greenwhich, CT: JAl Press.

Tomlinson, P. R. (2010). Co-operative ties and innovation: Some new evidence for UK manufacturing. Research Policy, 39(6), 762-775. doi: 10.1016/j.respol.2010.02.010

Tushman, M. L. \& Anderson, P. (1986). Technological discontinuities and organizational environments. Administrative Science Quarterly, 3/ (3), 439-465. doi: 10.2307/2392832

Tushman, M. L. \& Murmann, P. ( 1998). Dominant designs, technology cycles and organizational outcomes. Research in Organizational Behavior, 20, 23 I-266. doi: 10.5465/apbpp. 1998.27643428

Utterback, J. M. (1994). Mastering the dynamics of innovation. Cambridge, MA: Harvard Business School Press.

Von Burg, U. \& Kenney, M. (2003). Sponsors, communities, and standards: Ethernet vs. token ring in the local area networking business. Industry and Innovation, I 0(4), 35 I-375. doi: I0. I 080/ I 36627 I032000 I 6362 I

Weber, R. P. (1990). Basic content analysis. Newbury Park, CA: Sage. doi: | 0.4 |35/978|4|2983488

Yami, S., Chappert, H. \& Mione, A. (2015). Séquences stratégiques relationnelles: le jeu coopetitif de Microsoft dans le processus de normalisation OOXML. M@n@gement, 18(5), 330-356. doi: 10.3917/ mana. 185.0330

Yami, S. \& Nemeh, A. (20|4). Organizing coopetition for innovation: The case of wireless telecommunication sector in Europe. Industrial Marketing Management, 43(2), 250-260. doi: 10.1016/j. indmarman.2013.11.006

Yin, R. K. (2009). Case study research. Design and methods (4th ed.). Applied Social Research Methods Series, Vol. 5. Thousand Oaks, CA: Sage. 